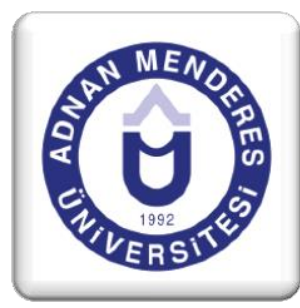

\title{
AB Bölgesel Politikası Kapsamında Mekansal Gelişme: Interreg ve Espon
}

\section{Spatial Development within the EU Regional Policy: Interreg and Espon}

\author{
Dr. Çiğgem ŞAHİN ${ }^{1}$
}

\section{Özet}

AB Bölgesel Politikası'nın, 1990'lı yılların sonuna kadar somut ve geniş çaplı bir mekansal planlama anlayışını içermediği görülmektedir. Ancak 1999 yılında Yapısal Fonların dağıtımında mekansal bir bir strateji öngören Avrupa Mekansal Gelişme Perpektifi (AMGP) belgesinin kabul edilmesinin ardından, başta çeşitli programlar yoluyla, mekansal planlama bölgesel gelişme anlayışında yer edinmeye başlamıştır. Bölgelerarası farklılıların mekansal olarak sergilediği dengesiz görünümün orta vadede giderilebilmesi için uygulanması önerilen AMGP'nin ilan edilmesinin ardından, bu mekansal planlama girişimiyle organize edilen programlardan günümüze gelmiş̧ iki program öne çıkmaktadır: Interreg ve Espon. Varlıklarını sürdürmekte ve kapsamları genişletilmiş olmaları itibariyle önemli gördüğümüz bu iki programın gelişimi ve işleyişlerinin tanınması, önemlidir. Bu çalışmada, öncelikle programların mekansal anlayış temelini oluşturan AMGP hakkında bilgi verilecek, ardından Interreg Programı ve geniş şekilde Espon Programı́nın gelişim, içerik ve somut sonuçları değerlendirilecektir.

Anahtar Kelimeler: Bölgesel Politika, Yersel Uyum, AMGP, Interreg, Espon

\footnotetext{
${ }^{1}$ Uzm., Ardahan Üniversitesi, Çıldır MYO, Turizm ve Otel İşletmeciliği Programı ilhamimorcin@ardahan.edu.tr
} 


\begin{abstract}
EU Regional Policy has not included a broad and concrete understanding of spatial planning until the end of the 1990s. After the adoption of European Spatial Development Perspective (ESDP) document envisioning a spatial strategy for the distribution of Structural Funds in 1999, spatial planning has begun to take place in regional development understanding. As a result of the ESDP, of which implementation was recommended to eliminate the unbalanced situation of regional differences in the medium term, two organized programmes became prominent: Interreg and Espon. It is very important to analyze these two comprehensive programmes to see the level of implementation success of spatial dimension. This study aims to elaborate the ESDP which is at the basis of spatial dimension and evaluate the Interreg and Espon Programmes in detail.
\end{abstract}

Keywords: Regional Policy, Territorial Cohesion, ESDP, Interreg, Espon

\title{
1. Giriş
}

1990'lı yılların başından itibaren geri kalmışlıkları ortak özellikleri olan belli coğrafi yapılar, AB'nin gündeminde daha fazla yer almaya başlamışlardır. İlk safhada çok yoğun olmamakla birlikte, AB'nin Uyum Politikası geliştikçe ve Bölgesel Politika dahilinde fonlar aracıllı̆̆yla verilen desteklerin yönelimleri düzenlendikçe, bölgeler arası farklılıklarda geri kalmışlıklarıyla öne çıkan alanlara (yerlerterritories) daha fazla vurgu yapılmaya başlanmıştır. 2000'li yıllarda Lizbon Stratejisi'yle uyumlu şekilde yürütülmesi hedeflenen Bölgesel Politika/Uyum Politikası ve Yapısal araçlar, bölgeler arası gelişmişlik farklarının giderilmesi için, bölgeler arası işbirliği yoluyla da bu çabaların desteklenmesi yönünde kurgulanmıştır. Genişleme, $\mathrm{AB}$ içindeki ve dişındaki pek çok gelişme ve asıl son ve en önemli faktör olarak 2008 yılında yaşanan ekonomik krizin büyük etkisiyle Lizbon Stratejisi hedeflerine ulaşılamamıştır. Krizle baş edebilme konusunda bazı ülkeler açısından çok ciddi sorunlar yaşanması, AB'nin yapısal anlamda bu tür gelişmelere hızlı cevap verebilme kapasitesini sorgulatmıştır. Bu etkiler sonucunda 2010 yılında başlatılan 'Avrupa 2020: Akıllı, Sürdürülebilir ve Kapsayıcı Büyüme Stratejisi', AB'nin gelecek on yıldaki ekonomi yönetimin hatlarını oluşturmaktadır. Bu Strateji doğrultusunda güncellenen ve reforme edilen politika ve araçlar, hala AB'nin en önemli sorunlarından biri olan bölgeler arası gelişmişlik farkları konusundaki çözüm beklentilerini yansıtırken, tüm politikalarda olduğu gibi Bölgesel/Uyum Politikası'nda da eskiye oranla daha fazla Strateji'ye tam bağlı amaç ve hedefler vurgusu göze çarpmaktadır.

Bölgeler arası gelişmişlik farkl1lıkları sorunu, AB'nin nihai amaç ve hedeflerinin önünde bir engel teşkil etmesiyle birlikte, yıllar geçtikçe düzenlenen ilgili politikaların da merkezine yerleşmiştir. Üretilen çözüm reçetelerinde, bölgesel/yersel uyum konusu zamanla belirleyici bir unsur haline gelmeye başlamıştır. İşte bu gelişmelerde, üzerinde pek durulmamış olmakla birlikte, AB'de mekansal planlamanın somut yansımalarına öncülük eden ve 1999 yılında ilan edilen Avrupa Mekansal Gelişme 
Perspektifi'nin (AMGP) rolü ve etkisi de önemlidir. Ancak bu Perspektif belgesi tek başına, AB için bir mekansal planlama anlayışı geliştiren ve önerilerde bulunan bir rehberdir. Uygulamaya yönelik değişik düzeylerdeki yansımaları ise, $\mathrm{AB}$ çapındaki somut programlar yoluyla kendini göstermektedir. $\mathrm{Bu}$ programlardan en belirgin ikisi yapısal fon destekli INTERREG ve ESPON Programları'dır. Dolayısıyla bu programların gelişimlerinin, amaç ve hedeflerinin, içerik ve sonuçlarının bilinmesi, AB'de mekansal boyutun Bölgesel Politika/Uyum Politikası dahilindeki rolünün görülmesi, yersel anlayışın ne şekilde ve ne dereceye kadar somutlaştırıldığının anlaşılması açısından önemlidir.

Çalışmada öncelikle AMGP, ardından sırasıyla Interreg ve Espon Programlarının gelişim, içerik ve sonuçları incelenmiştir. Henüz geliştirilme aşamasında olan programların 2014-2020 versiyonları, Avrupa 2020 Stratejisi ve yeni yapısal destek anlayışı kapsamında değerlendirilmiş, Türkiye'nin programlarla olan ilişkisi ele alınmıştır. Sonuçta ise, bu programların yersel uyum anlayışıyla ilgili sonuçlarına ve önerilere yer verilmiştir.

\section{Çalışmanın Kapsamı ve Yöntemi}

Avrupa mekansal planlaması, 1999 yılında AMGP ilan edildiğinde, başlıca üç birbiriyle ilişkili program ve girişim çerçevesinde organize edilmiştir. Bunlar INTERREG IIC, Tempare AMGP Eylem Programı (Tempare ESDP Action Programme- TEAP) ve Avrupa Mekansal Planlama Çalışma Programı'dır (Study Programme on European Spatial Planning- SPESP). Mekansal planlamada ulus ötesi işbirliğini geliştirme amacıyla uygulanan INTERREG IIC Programı, Avrupalı planlamacılar tarafindan AMGP'nin mesajlarının test edilmesi olarak düşünülmüştür. Sonraki yıllarda Programın bir Topluluk Girişimi olarak düzenlenmiş olması ve Avrupa Komisyonu tarafından finanse ve idare edilmesi, Topluluk düzeyinde mekansal planlamanın denenmesi anlamına gelmektedir. Tempare AMGP Eylem Programı, pek etkin sonuçlar doğurmamıştır. Üçüncü olarak Avrupa Mekansal Planlama Çalışma Programı ise, yine INTERREG kapsamında uygulanan bir pilot program olarak kurgulanmıştır. 1998-2000 yılları arasında uygulanmıştır ve günümüzdeki ESPON (European Spatial Planning Observation Network- Avrupa Mekansal Planlama İzleme Ağı) programının temelini oluşturmuştur. ESPON, 1990'1 y yllarından itibaren Avrupa mekansal planlamacılarının AMGP kapsamında temel başarılarından biri olarak görülmektedir (Waterhout, 2008: 8-9). Dolayısıyla, AB'de Bölgesel Politika-Uyum Politikası kapsamında özellikle 2007-2013 program döneminde somut olarak mekansal planlama uzantıları olarak da ifade edilebilecek uygulamalar olarak, INTERREG Programı ve ESPON Programı öne çıkmaktadır. Bu programların temelinde yer alan AMGP, programların düşünsel altyapılarıyla örtüşen boyutları itibariyle önemlidir.

Çalışma temel olarak $\mathrm{AB}$ mevzuatındaki ilgili belgelerin, $\mathrm{AB}$ düzeyindeki analizlerin ve programlarla ilgili çalışmaların incelenmesi neticesinde, INTERREG ve daha detaylı olarak ESPON tarihsel gelişim ve uygulama dönemleri itibariyle teknik olarak değerlendirilmiş ve ilgili literatür çalışmalarıyla desteklenmiştir.

\section{Avrupa Mekansal Gelişme Perspektifi}

Avrupa Mekansal Gelişme Perspektifi - AMGP (European Spatial Development Perspective- ESDP), 1999 yılında kabul edilen ve Avrupa Komisyonu tarafindan yayınlanan, AB coğrafyasındaki dengeli ve sürdürülebilir bir kalkınma için, ekonomik ve sosyal uyum politikalarının mekana yansıması ve mekansal sonuçlarının değerlendirilip, geleceğe yönelik bir mekansal gelişme stratejisine sahip olunması gereğini açıklayan bir strateji belgesidir (European Commission, 1999). Bölgesel politika konusunda çok fazla üzerinde durulmamakla birlikte, aslında Avrupa alanındaki gelişme eksenlerine ilişkin tamamlayıcı ve açıklayıcı bir perspektiftir. Bölgeler arası gelişmişlik farklarına 'mekansal gelişme farklılıkları' açısından yaklaşan belgede, AB'nin bölgesel olarak dengeli ve sürdürülebilir mekansal gelişmesinin gerçekleştirilebilmesinin önünde duran büyük ekonomik dengesizliklere vurgu yapılmaktadir.

\subsection{AMGP'nin Gelişimi}


Mekansal planlamanın Avrupa boyutunda değerlendirilmesi yolunda atılan ilk adımlar, AB'nin mekansal planlamadan sorumlu Bakanlarının gündeminde ve çalışmalarında yer almıştır. AMGP'nin ortaya çıkmasına ilişkin ilk girişimler, 23-24 Kasım 1989 tarihinde düzenlenen konuya ilişkin bakanların toplantısına dayanmaktadır. Burada doğrudan AMGP'nin adıyla bir karar alınmamış, ancak Avrupa'da mekansal planlamaya yönelik toplantıların sürdürülmesi ve bir çalışma yapısı oluşturulması kararı alınmıştır. Sonraki birkaç yıl bazı temel gelişmeler dışında, bu niyet pek uygulamaya geçmemiştir. Asıl AMGP'nin somut olarak doğması ise, 12-13 Kasım 1993 tarihinde bölgesel gelişme ve çevre konularından sorumlu bakanların katılımıyla Belçika Liege'de toplanan Bakanlar toplantısında gerçekleşmiştir. Burada, Avrupa mekansal planlamasına yönelik bir belgenin hazırlanması hakkında ilk teklif verilmiştir (ESPON Project 2.3.1: 18). Düşüncelerin ortaya konmasından somut çalışmaların başlatılmasına kadar birkaç yıl geçmiş olmasını, özellikle Soğuk Savaş'ın bitiş döneminin yaşanıyor olması, bu sebeple SSCB'nin dağılmasıyla Avrupa'nın doğuya doğru açılması, Maastricht Antlaşması gelişmesinin yaşanması gibi temel nedenlere bağlanmaktadır (Caudullo, 2007: 13). Böylesi gelişmelerin ve dönüşümün gösterdiği üzere, bir Avrupa Mekansal Planlaması belgesine ihtiyaç da somutlaşmıştır.

1994 y1lı somut adımların daha belirginleştĭgi yıl olmuştur. Önce 3-4 Haziran 1994'te Corfu'da bir çerçeve belge ve yersel planlamaya yönelik seçenekler belirlenmiş, ardından 21-22 Eylül 1994'de Leipzig'de bir Avrupa Mekansal Gelişme Politikası'na ilişkin temel prensipler belirlenmiş, ilk yersel proje tasarısının hazırlanmasına karar verilmiştir. Denilebilir ki, 1999 yılında ilan edilen belgenin temel ve içeriğine ilişkin ilk kararlar bu toplantıda yapılan görüşmeler neticesinde alınmıştır. Gelecekte uygulanacak olan AMGP'nin bağlı olması istenen prensiplerle birlikte, bu prensiplerin uygulanmasında takip edilmesi gereken temel hedefler de tanımlanmıştır (BMBau, 1994: 2). Ekonomik ve sosyal uyuma destek olma ve sürdürülebilir kalkınmayı sağlama amaçlarıyla birlikte, AMGP'nin rolü, "kendisi için belirlenmiş olan bu temel amaçların yersel etkilerini tanımlamak ve bunları tüm Avrupa için bir mekansal gelişme perspektifinin operasyonel hedefleriyle bütünleştirmek" olarak belirlenmiştir. $\mathrm{Bu}$ genel amaçlar doğrultusunda belirlenen operasyonel hedefler ayrıca tanımlanmıştır (BMBau, 1994: 4-5): Ekonomik ve çevresel gelişme daha sağlam ve dengeli bir mekansal yapı üzerinde temellendirilmeli ve başta bölgesel kimliklerin çeşitliliği olmak üzere, Avrupa Birliği’ne has diğer unsurlarla birlikte hareket edilmelidir; Ekonomik gelişme, kültürel ve doğal mirasın iyi yönetimi ve geliştirilmesi düşüncesiyle bütünleştirilmelidir; Mekansal gelişme politikaları kalkınma, denge sağlama ve koruma hedefleriyle birlikte yürütülmelidir.

Bir başka boyutta ise, bir AB Antlaşması'nda temellendirilmemiş ve yasal güç verilmemiş olan AMGP'nin, üye devletlerin üzerinde bağlayıcı tutulmaması ve gönüllü eylemler temeline sahip görülmesiyle, aslında kısa vadede uygulamanın ne şekilde olacağına ilişkin sorunların da düşünüldügünü göstermektedir (Richardson ve Jensen, 2000: 506-507). Netice itibariyle uygulamadaki ilk örnek, INTERREG gibi proje temelli bir ulus ötesi işbirliği olmuştur. 9-10 Haziran 1997 tarihinde ilk AMGP taslağının sunulmasının ardından, çeşitli platformlarda yapılan düzenlemeler neticesinde son metin üzerinde görüş birliğine varılmış ve 10-11 Mayıs 1999 tarihinde Potsdam Bakanlar Toplantısı'nda belge kabul edilmiştir (Final Conclusions, 1999). İşlevine bakıldığında, Topluluğun yapısal fonlarının dağıtımı için mekansal bir strateji oluşturmak olan AMGP, AB'nin faaliyetlerinde resmi bir pozisyona sahip olmadığı için zorunlu değil, yol gösterici bir belge olarak kurgulanmış, üye devletlere, onların bölgelerine, yerel yönetimlere AB'nin kendi sorumluluk alanlarına hizmet eden politik bir çerçeve olarak sunulmuştur (Demirci ve Genç, 2007: 59).

\subsection{AMGP'nin Amaçları ve Kapsamı}

AMGP belgesi, kendi gerekçesini bölgesel dengesizler üzerinden tanımlamaktadır. Ekonomik potansiyelin dengesiz dağılımı mekansal bir düzlemde ele alındığında, 1990'ların sonunda şöyle bir görünüm ortaya çıkmaktadır: AB'nin merkezinde yer alan Londra, Paris, Milano, Münih ve Hamburg metropollerini içeren alan $\mathrm{AB}$ nüfusunun \%40'ını içermekte, $\mathrm{AB}$ toplam GSYIH'nin yaklaşık $\% 50$ 'sini üretmekte ve $\mathrm{AB}$ topraklarının \%20'sini oluşturmaktadır. Ancak AB'nin güney sınırında Portekiz'den güney İspanya'ya uzanan, güney İtalya ve Yunanistan ile yeni Alman Lander'i içeren alanda kişi başına GSYIHH oranı, AB ortalamasının ancak \%50-65'ine ulaşmaktadır. AB topraklarının 
kuzeyinde yer alan kuzey Finlandiya, kuzey İngiltere gibi bölgelerde ekonomik durum çok daha iyi düzeydeyken, diğer yandan deniz aşırı topraklarda çoğunlukla $\mathrm{AB}$ ortalamasının \%50'sinin altında kalınmaktadır. Mekansal olarak bu dengesiz görünümün orta vadede daha dengeli bir gelişme göstermesi için, AMGP'nin uygulanması önerilmektedir (European Commission, 1999: 8).

AMGP, aslında amaçları itibariyle ekonomik ve sosyal uyumla bire bir örtüşen bir yaklaşımdır. Temel amacı, özelde sosyal ve ekonomik uyumun güçlendirilmesi yoluyla, $\mathrm{AB}$ 'nin dengeli ve sürdürülebilir bir kalkınmayı sağlamasıdır. Perspektifin önerisi, burada özellikle sürdürülebilirlik boyutundan hareket etmektedir; sürdürülebilirliğin tek kriteri sadece çevreye duyarlı ekonomik gelişme değildir, aynı zamanda mekansal gelişmede dengeyi de gerektirmektedir. Bu doğrultuda ekonomik ve sosyal uyum, doğal kaynakların ve kültürel mirasın korunması ve Avrupa coğrafyasında daha dengeli bir rekabetçilik ayakları üzerine temellendirilmiş bir AMGP, geleceğin bölgesel dengesizlikleri azaltılmış ve aynı zamanda dengeli kalkınmış AB'si için ortaya konmaktadır (European Commission, 1999: 1011). Bunun için de, Yapısal Fonlar başta olmak üzere, mekansal yansımaları yoğun olan ancak çoğunun içeriklerinde buna ilişkin düzenleme yapılmamış AB politikaları (rekabet politikası, TransAvrupa Ağları-TENs, ortak tarım politikası, çevre politikası, araştırma-teknoloji-geliştirme politikaları, AYB kredileri), AMGP doğrultusunda işlemelidir. $\mathrm{Bu}$ belgeyle, bölgesel bağlamda, aşağıda sayılan hususlar $\mathrm{AB}$ ajandasını oluşturması gereken en önemli konular arasında sayılmışlardır: “... kentle kır arasındaki dengeyi hedefleyen, merkez-çevre ilişkisini güçlendiren, rekabetçi ve dinamik kentsel alanların yanı sira kırsal alanda verimli ve üretken yerel kalkınmayı destekleyen, çok merkezli bir mekânsal gelişme öngörülmüştür. Tek şehir etkisiyle gerçekleşen gelişmelerin ülkesel boyutta yarattığ sakıncalar özellikle vurgulanarak, kir-kent arasında işbirliklerinin geliştirilmesi ve bu alanlar arasında erişebilirliğin artırılması..." (DPT, 2008: 131).

Bu mekansal gelişme yaklaşımı tüm Yapısal Fonlar alanında kendini fazla göstermemiştir. Ekonomik odağın, sosyal, çevresel ve kültürel odaklardan daha ağırlık bir yapıya sahip olması, istatistiksel olarak AB'nin ölçüm yapabileceği mekanları, sınırları bölgeler (NUTS) olarak organize etmesinin temelini oluşturmuştur. Bu perspektifin tam olarak olmasa da daha büyük yansımaları, 2007 sonrasında Uyum Politikası kapsamında kurgulanan Bölgesel Politikada biraz daha hissedilmektedir.

Bölgelerarası farklılıkların mekansal olarak sergilediği dengesiz görünümün orta vadede giderilebilmesi için uygulanması önerilen AMGP'nin ilan edilmesinin ardından, bu mekansal planlama girişimi, tüm Birlik boyutunda bağlayıcı bir düzenleme olmamakla birlikte, tüm Birlik boyutunda (ve ortak ülkeleri de kapsayan) organize edilen Yapısal Fonlar destekleri kapsamındaki programlar üzerinden deneyimlenmeye başlanmıştır. $\mathrm{Bu}$ şekilde günümüze gelmiş iki önemli programdan birincisi INTERREG Programı'dır. AMGP'nin düşünsel yapısının kısmi olarak da olsa 2000-2006 döneminden itibaren, öncelikle bu Program üzerinden uygulandığı görülmektedir. Avrupa Bölgesel Kalkınma Fonu tarafindan finanse edilen program, 25 yıldan uzun süredir AB fonlar gündeminde yer alması itibariyle de önemlidir.

\section{INTERREG Programı}

1988 yılından itibaren fiilen uygulanan programın mali dönemler itibariyle gelişimi, amaçları, yapısı, kapsamı incelendiğinde, özellikle 2007'den itibaren programın daha ciddi boyutta ele alındığ görülmektedir. Topluluk düzeyinde bir hedef olan Avrupa Yersel İşbirliği Hedefi olarak kurgulanarak devam etmesi, mekansal boyutun Lizbon Stratejisi'nin ikinci döneminde ekonomik ve sosyal uyuma, yersel uyum boyutunun eklenmesiyle gerçekleşmiştir. Aşağıda önceki dönemler itibariyle kısaca ele alınan programın kapsamlı yapısı, 2007-2013 döneminde değerlendirilecektir.

\subsection{INTERREG I (1990-1993)}

Sınır ötesi, ulus ötesi ve bölgelerarası işbirliğinin tüm Avrupa'da dengeli bir şekilde geliştirilmesi yoluyla, AB'de ekonomik ve sosyal uyumun güçlendirilmesi için tasarlanmış bir girişim olarak varlığını sürdürmüş INTERREG, ilk olarak Avrupa Komisyonu'nun toplam 21 milyon ECU bütçeyle desteklediği 14 sınır ötesi pilot projeden biri olarak 1988-89 yılında başlatılmıştır (Association of European Border Regions, 1997: 6). Bu pilot projeler, ABKF Tüzüğü’nün 10. Maddesi kapsamında 
başlatılmış ve bu fon üzerinden desteklenmiştir (Regulation (EEC) No 724/75). 1990 y1lında ise, sınır bölgelerine yönelik bir Topluluk girişimi olarak düzenlenmiş ve üye ülkelerin katılımına ilişkin hususları düzenleyen INTERREG Rehberi, 30 Ağustos 1990 tarihinde ilan edilmiştir (Notice C(90) 1562/3). 1990-1993 dönemine ilişkin olarak programa 1.082 milyon ECU bütçe ayrılmış ve büyük bölümünün Hedef 1 bölgelerine yönelik olarak kullanılması öngörülmüştür. Hedef 1 dışında kalan sınır bölgelerine sadece 125 milyon ECU pay ayrılmıştır. INTERREG I döneminde bölgesel olarak, finans miktarı olarak ve tarafların kapsamın itibariyle birbirinden farklı 31 operasyonel program desteklenmiştir. INTERREG I'in başlatılması, çok katmanlı yönetişim sistemi yöneliminde önemli bir adım olarak görülmektedir. $\mathrm{Bu}$ girişimle birlikte tüm Topluluk girişimleri, Topluluğun fon finansmanının sadece üye devletlere ya da bölgelerine değil, aynı zamanda doğrudan belirli sınır ötesi yapılara da (Euroregions ya da Euregios) tahsis edilebileceğini göstermiştir (Panteia, 2010: 23). Böylelikle aslında Topluluğun Avrupa Komisyonu üzerinden yeni bir merkezi olmayan bölgesel politika anlayışına da çok soğuk bakmadığı görülmüştür.

\subsection{INTERREG II (1994-1999)}

1992 Edinburg Zirvesi'nde INTERREG kapsamında sınır ötesi işbirliğine devam edilmesinin bir öncelik olarak kararlaştırılmasının ardından, Avrupa Komisyonu 1 Temmuz 1994 tarihinde INTERREG II Rehberi'ni yayınlayarak, 1994-1999 döneminde programdan faydalanma esaslarını açıklamıştır (Notice to The Member States (94/C 180/13)).Rehberde açıklanan INTERREG II programının amaçları şunlardır:

-AB'nin iç ve dış sınır bölgelerini, hem Birlik hem de ulusal ekonomiler dâhilinde nispeten izole durumlarından kaynaklanan gelişme sorunlarını çözmek üzere desteklemek;

-1992 tek Pazar hedefi kapsamında, iç sınırlar boyunca işbirliği ağları kurmak ve geliştirmek, mümkün ölçüde bu işbirliği ağlarını daha geniş Topluluk ağları kapsamında birbiriyle bağlantılı hale getirmek;

-Dış sınır bölgelerinin, bütünleştirilmiş bir pazarın dış sınırları haline gelmelerinden kaynaklanan yeni rollerine uyumlaştırılması için desteklemek;

-Topluluğun dış sınırlarında bulunan bölgelerde, üçüncü ülkelerle yeni işbirliği firsatlarını kullanmak; -Seçilmiş enerji ağlarını tamamlamak ve bunları daha geniş Avrupa ağlarıyla bağlantılı hale getirmek.

$\mathrm{Bu}$ genel amaçlarla başlatılan INTERREG II'nin, 2 farklı kola ayrılarak uygulanması kararlaştırılmıştır: INTERREG IIA (sınır ötesi işbirliği) ve INTERREG IIB (enerji ağları). 1997 y1lından itibaren üçüncü bir kol daha geliştirilmiştir: INTERREG IIC (mekansal planlamada ulus ötesi işbirliği ve su kaynaklarının yönetimi). Bu yeni kolda AMGP'nin ilkeleriyle aynı doğrultuda, Avrupa coğrafyasında dengeli ve bütünsel bir mekansal gelişmenin sağlanması amaçlanmıştır (Panteia, 2010: 25). Programdan yararlanabilecek bir bölümü deniz sınır bölgelerini oluşturan NUTS Düzey 3 bölgeleri de, Rehber'in ekinde yayınlanmıştır. Yapısal Fonlar'ın 1994-1999 öncelikli hedeflerinden Hedef 1,2 ve $5 b$ (daha sonra Avusturya, İsveç ve Finlandiya'nın katılımı üzerine Hedef 6) bölgelerinden oluşan bu yararlanıcı sınır bölgelerinden bazıları, kısmı olarak hedeflere dahil olan bölgelerdir.

\subsection{INTERREG III (2000-2006)}

1990'lı yılların sonuna gelindiğinde, AB aslında Yapısal Fonlar kanalıyla desteklenen bölgesel işbirliğinin bölgeler arası dengesizlikleri gidermede, $\mathrm{AB}$ içinde ve dışında yaşanan gelişmelerin etkisiyle bir türlü yeterli olmadığını düşünmeye başladığı ve bir geçiş aşamasına doğru ilerleme sinyalleri verdiği görülmektedir. Özellikle Gündem 2000 belgesiyle ortaya konan gerçekler ve değişiklik yönelimleri ve sonrasında Yapısal Fonlar'da gerçekleştirilen reformla, AB'nin en ağır genişleme baskısı yaşadığı dönem için önlemler alınması planlanmış ve uygulamaya konulmuştur. $\mathrm{Bu}$ dönemde yaşanan sorunlara yönelik olarak, yersel işbirliğiyle bazı çözümlerin getirilmesi, yaklaşan büyük genişlemeyle de yersel işbirliği kapsamında büyük değişiklikler olacağı gerçeğinden hareketle de, bu işbirliğinin gelecekteki karmaşıklaşacak kurumsal kapsamının düzenlenmesi düşünülmüştür (Panteia, 2010: 27). Ancak bu düşünceler hemen uygulamaya konmamış, 2000-2006 dönemi, bir geçiş 
dönemi olarak kurgulanmıştır. INTERREG III böylesi bir geçiş döneminde başlatılmış ve uygulanmıştır.

\subsubsection{Programın Yapısı ve Kapsamı}

Avrupa Komisyonu'nun 28 Nisan 2000 tarihinde başlatma kararı aldığı INTERREG III, Genel Yapısal Tüzüğü'nün 20. Maddesi doğrultusunda (Council Regulation (EC) No 1260/1999), Avrupa'nın uyumlu ve dengeli gelişmesini desteklemek üzere trans-Avrupa işbirliği hakkında bir Topluluk Girişimi olarak düzenlenmiştir (Communication from The Commission to the Member States (2000/C 143/08)). ${ }^{2}$ Önceki dönemle aynı şekilde üç farklı kolda uygulanmıştır.

INTERREG IIIA olarak ifade edilen sınır ötesi işbirliği kapsamında, dış kara ve deniz sınırlarında, komşu sınır bölgeleri arasında bütünleştirilmiş bölgesel gelişmeyi sağlamak amaçlanmıştır. INTERREG IIIB ile ulus ötesi işbirliği ile Topluluk topraklarında bütünleşmenin ve uyumlu yersel gelişmenin sağlanmasına katkıda bulunmak amaçlanmıştır (önceki dönemde INTERREG IIC). Çok geniş bir coğrafyaya hitap etmekle birlikte, bu kapsamdaki programların sınırlı sayıda kilit konularda ulus ötesi işbirliğini geliştirme ve desteklemesi beklenmiştir. (Panteia, 2010: 27). INTERREG IIIC ise, bölgeler arası işbirliği, ise en geri kalmış bölgelerin gelişme potansiyellerini artırmak amacıyla destek sunmuştur. Belli bir sistem içinde ve kapsamlı bilgi alış verişi ve deneyimlerin paylaşılması yoluyla, bölgesel gelişme ve uyum politikası ile araçlarının etkinliğini sağlayarak bu desteği vermesi planlanmıştır. INTERREG IIIC'nin uygulanma yöntemine ilişkin ayrı Komisyon belgesi düzenlenmiş, öncelikli işbirliği konuları bu belgede beş eylem başlığı altında toplanmıştır (Communication from the Commission to the Member States (2001/C 141/02)): Yapısal Fonlar Hedef 1 ve 2 çerçevesinde desteklenen eylemler; diğer ilgili Interreg programlarına ilişkin kamu yönetimleri veya eşdeğer kurumları bir araya getiren bölgeler arası işbirliği; kentsel gelişim alanında bölgesel işbirliği; bilgi ve teknolojik yenilikçilik, bilgi toplumu, bölge kimliği ve sürdürülebilir kalkınma konularından en az biriyle ilişkili olarak bölgeler arası işbirliği; bölgeler arası işbirliğine yönelik diğer konular.

\subsubsection{Program Bölgeleri}

Genel olarak sınır ötesi işbirliğini geliştirmek ve AB'nin iç ve dış sınırlarında yer alan bölgelere, izole konumlarından kaynaklanan sorunların çözümünde yardımcı olmak amaçlarıyla kurgulanan INTERREG III girişimi, özellikle programlama ve ortaklık prensipleri doğrultusunda yönetilmiştir. Programdan yararlanma koşulları, yine üç ayrı dal için ayrı ayrı belirlenmiştir. INTERREG IIIA'dan yararlanabilecek olan bölgeler, AB'nin iç ve dış kara sınır bölgelerinde yer alan, belirli deniz sınırlarında yer alan ya da bu bölgelerin çevresinde/sınırlarında yer alan tüm NUTS Düzey 3 bölgeleri olarak belirlenmiş, liste halinde yayınlanmışlardır (Communication from The Commission to the Member States (2004/C 226/02)). ${ }^{3}$ INTERREG IIIB kapsamında, aslında tüm AB ve komşu bölgeler ulus ötesi işbirliği programlarının yararlanıcısı konumundadır. Bu duruma ilişkin olarak, yine liste haline 13 alan sıralanmış ve bu alanlar dahilinde yer alan bölgeler belirlenmiştir: ${ }^{4}$ Batı Akdeniz, Alpler, Atlantik, Güneybatı Avrupa, Kuzeybatı Avrupa, Kuzey Denizi, Baltık Denizi, Merkez Avrupa, Kuzey Çevre, Akdeniz, Karayipler, Azorlar-Madeira-Kanaya Adaları, Hint Okyanusu. INTERREG IIIC ise, prensipte tüm AB'nin yararlanmasına açıktır. Çıkarılmış olan Komisyon belgesiyle, üye ülkeler ve ilgili bölgeler, dört programlama kuşağı çerçevesinde belirlenmiştir (Communication from the Commission to the Member States (2001/C 141/02): ${ }^{5}$ Güney Kuşağı (İtalya 12 bölge, Yunanistan 8 bölge, Fransa 12 bölge, İngiltere 1 bölge, tüm Portekiz ve İspanya), Kuzeybatı Kuşağı (Fransa 13 bölge, Almanya 5 bölge, tüm İngiltere -Cibraltar hariç, İrlanda, Lüksemburg, Hollanda ve Belçika), Kuzeydoğu Kuşağ 1 (Almanya 5 bölge, tüm Danimarka, İsveç ve Finlandiya), Doğu Kuşağı (Almanya 6 bölge, İtalya 8 bölge, Yunanistan 6 bölge ve tüm Avusturya).

\footnotetext{
${ }^{2}$ Bu ilk yayınlanan INTERREG III Rehberi önce 2001 yılında, ardından 2004 yılında iki kez değişikliğe uğramıştır (Communication from the Commission (2001/C 239/03); Communication from The Commission to the Member States (2004/C 226/02)).

${ }^{3}$ Annex I: Strand A Eligible Regions.

${ }_{5}^{4}$ Annex III: Strand B Eligible Areas (Communication from The Commission to the Member States (2004/C 226/02))

${ }^{5}$ Annex A: Programming Areas.
} 
Program dönemi boyunca INTERREG III için 4.875 milyon Euro, ABKF'den tahsis edilmiştir. Program kapsamında uygulanan iki önemli alt program, yine yersel işbirliğini desteklemeye yönelik olarak düzenlenen ESPON ve INTERACT'tır. ESPON, sonraki kısımlarda detaylı olarak değerlendirilecektir.

\subsection{Avrupa Yersel İşbirliği Hedefi (INTERREG IVC/2007-2013)}

2007-2013 dönemi, Lizbon Stratejisi’nin etkisiyle kurgulanmış ve onunla daha bütünleştirilmiş bir Bölgesel Politika ve Yapısal Fonlar sürecini ifade eden Uyum Politikası yapısıyla başlayan bir dönemdir. Bu alanda yapılan tüm düzenlemeler, AB'nin ekonomik, sosyal ve yersel uyumuna yönelik tedbirleri hayata geçirmeye yönelik olmuştur. Lizbon'la belirlenen (ardından güncellenen) bilgi toplumu ve daha fazla ve iyi istihdam hedefleri, Yapısal Fonlar ve ilgili programların yapısına ve işleyişine de doğrudan yansımış ve teknik olarak yeni bir programlar düzeni yapılandırılmıştır. INTERREG Programı da, bu yeni dönemde görevi ve önemi itibariyle farklılaşmıştır. 2007-2013 dönemi oluşturulan yeni sistemde Yakınsama Hedefi, Bölgesel Rekabetçilik ve İstihdam Hedefi, Avrupa Yersel İşbirliği Hedefi üç topluluk hedefi olarak belirlenmiştir (Coucil Regulation (EC) No 1083/2006). Bu hedeflerden üçüncüsü olan Avrupa Yersel İşbirliği, önceki INTERREG III Topluluk Girişimi’nin devamı niteliğindedir.

\subsubsection{Programın Yapısı ve Kapsamı}

Bir girişim olmaktan çıkıp bir Hedef olarak kurgulanan bölgesel işbirliği, daha fazla önem verilen ve üst düzeyde yapılandırılan bir alan olarak karşımıza çıkmaktadır. Bu durumun temel sebeplerinden biri, $\mathrm{AB}$ sınırlarında yer almalarına rağmen, $\mathrm{AB}$ üyesi olmadıkları için fon kaynaklarından yararlanamayan devletlerle işbirliğini geliştirmektir (Norveç, İsviçre, Lihtenştayn gibi). Bu hedefle denizlerdeki işbirliği sınırları da geniş tutulmuş, Avrupa merkezli ve Avrupa çevresini de kapsayan bir işbirliği alanı oluşturulmak hedeflenmiştir. Bir diğer asıl önemli sebep ise, bölgelerin yenilenmiş Lizbon stratejisinin önceliklerine uyumlarının sağlanması ve geliştirilmesi isteğidir. İşbirliği yoluyla bu amaca hizmet edilerek hem $\mathrm{AB}$ fon desteği mümkün olacak, hem de yararlanıcı tüm düzeylerdeki aktörlerin finansmana ve operasyonel sürece katılımları ve sorumluluğu paylaşmaları mümkün olacaktır.

INTERREG Programının yeni yapısında, önceki INTERREG IIIC kolu altındaki tüm programlar, tek bir INTERREG IVC olarak düzenlenmiş̧tir. Tam adı 'Bölgelerarası İşbirliği Programı INTERREG IVC'dir ve Avrupa Yersel İşbirliği Hedefi kapsamında 3 ağ programıyla birlikte (Urbact II, Interact II ve ESPON 2013) 'Bölgelerarası işbirliği'ni ifade etmektedir. INTERREG IVA, hedef kapsamındaki sınır ötesi işbirliği programlarını belirtmek için kullanılırken, INTERREG IVB ise ulus ötesi işbirliği programlarını ifade etmektedir. INTERREG IVC ise, AB üyesi ülkeler ile Norveç ve İsviçre'yi kapsayan operasyonel programdır. Diğer 3 ağ programı ile desteklenmektedir (Urbact II, Interact II ve ESPON 2013). ABKF'nin toplam katk1s1 445 milyon Euro'dur. ${ }^{7}$ INTERREG IVC Program1, Fransa'nın üye devletler adına Nisan 2007'de Komisyon'a başvurusunun ardından 11 Eylül 2007 tarihli Komisyon Kararı ile başlatılmıştır (Commission Decision C (2007) 4222). 1 Ocak 2007-31 Aralık 2013 dönemi boyunca süren INTERREG IVC Uygulama Programı da aynı karar ekinde yayınlanmıştır. Önceki dönemlere göre daha az konuya odaklanılırken, programın izlenmesi sürecinin daha sıkı bir sisteme tabi tutulduğu farklılığı görülmektedir.

\subsubsection{Programın Amaç, Hedef ve Öncelikleri}

Programın genel amacı, "Bölgelerarası işbirliği yoluyla, yenilikçilik, bilgi ekonomisi, çevre, riskleri önleme alanlarında bölgesel gelişmenin etkinliğini artırmak, ayrıca Avrupa'nın modernleşmesine, rekabet gücünün artmasına, sürdürülebilir kalkinmasina ve yersel uyumu sağlamasina katkıda

\footnotetext{
${ }^{6}$ Interact I Programı hakkında detaylı bilgi için;(Çevrimiçi) http://www.interact-eu.net/interact1/interact i/119/564 3.2.2012.

${ }^{7}$ (Çevrimiçi) http://ec.europa.eu/regional_policy/cooperate/cooperation/index_en.cfm 17.3.2012
} 
bulunmak." olarak belirlenmiş ve bu genel amaç doğrultusunda, Program'ın eylem alanlarını da gösteren alt hedefler ortaya konmuştur. Bu hedefler aynı zamanda bölgelerin etki yaratılmak istenen politika ve araçlarını da göstermektedir. Hedefler, Tematik ve Yatay Hedefler olmak üzere, iki türlü belirlenmiştir (Interregional Cooperation Programme, 2011: 36-37):

\section{Tematik Hedefler:}

1. Yenilikçilik ve bilgi ekonomi alanlarında bölgesel ve yerel politikaları güçlendirmek (girişimcilik ve KOBI'lerin desteklenmesi, iş çevrelerinin ve yenilikçilik girişimlerinin desteklenmesi, BİT kullanımının geliştirilmesi, istihdam, insan kaynakları ve eğitimin desteklenmesi).

2. Çevre ve risklerin önlenmesi alanlarında bölgesel ve yerel politikaları güçlendirmek (su ve kıyı yönetimi, atık önleme ve yönetimi, biyo çeşitlilik ve doğal mirasın korunması, enerji etkinliği ve yenilenebilir enerji, temiz ve sürdürülebilir kamu taşımacılığı, kültürel mirasın desteklenmesi).

\section{Yatay Hedefler:}

1. AB çapında farklı üye ülkelerden bölgesel ve yerel düzeylerde aktörlerin, bilgi ve deneyimlerini paylaşmalarını sağlamak.

2. Bölgesel ve yerel paydaşların bilgi ve yeteneklerini ortaklık yoluyla geliştirmeleri amacıyla, belirli bir alanda daha az deneyimli olan bölgelerle o alanda daha fazla deneyimli bölgeleri buluşturmak.

3. Bölgelerarası işbirliği projeleriyle ortaya çıkan iyi uygulamalara, diğer bölgesel ve yerel aktörlerin erişimini, ayrıca bu iyi uygulamaların başta Yapısal Fonlar programları olmak üzere, bölgesel politika alanına aktarılmalarını sağlamak.

$\mathrm{Bu}$ hedefler doğrultusunda, Program'ın öncelikleri de oldukça detaylı şekilde tanımlanmıştır. Teknik Destek konusunun da (programın etkin ve iyi yönetilmesi ve uygulanması için verilecek destek) bir öncelik olarak belirlenmesiyle birlikte, INTERREG IVC'nin 2 temel Önceliği ve bunlara bağl1 temaları bulunmaktadır. Bu öncelikler, Tematik Hedefleri de ifade etmektedir (Interregional Cooperation Programme, 2011: 46-55):

Öncelik 1: Yenilikçilik ve bilgi ekonomisi- Yenilikçilik, araştırma ve teknolojik gelişme; Girişimcilik ve KOBİ'ler; Bilgi toplumu; İstihdam, insan kaynakları ve eğitim.

Öncelik 2: Çevre ve risk önleme- Doğal ve teknolojik riskler; Su yönetimi; Atık önleme ve yönetimi; Biyo çeşitlilik ve doğal mirasın korunması; Enerji ve sürdürülebilir taşımacılık; Kültürel miras ve peyzaj.

INTERREG IVC kapsamında desteklenen projeler, iki ana grupta değerlendirilmektedir: Bölgesel Girişim Projeleri (Regional Initiative Projects), INTERREG IIIC programındaki klasik bölgelerarası işbirliğini geliştirme amaçlı projelerdir. Aktifleştirme Projeleri (Capitalization Projects) ise, ortakların tanımlanmış iyi uygulamalar geliştirmeleri şeklinde belirlenmiştir. Bu tür projeler, iyi uygulamaların AB Yapısal Fonlar programlarına aktarımı için kurgulanmıştır. Eylem planları üzerinden uygulanan aktifleştirme projeleri kapsamında, Komisyon'un kendi seçimiyle belirlenen bir proje türü daha yer almaktadır: Hızlı Kulvar Projeleri (Fast Track Projects). Bunlar da belirli bir bölgesel iyi uygulamanın alınarak bir ya da daha fazla bölgeye aktarılması yoluyla uygulanmaktadırlar (Interregional Cooperation Programme, 2011: 39-41).

\subsubsection{Programın Bütçesi}

INTERREG IVC Programı için ABKF'den tahsis edilen destek toplam 321 milyon Euro'dur (üç ăg programı hariç). En fazla desteğin AB'nin genel stratejisi doğrultusunda Yeniliçilik ve Bilgi Ekonomisi önceliğine ayrıldığı görülmektedir. Bununla birlikte ulusal katkının da en fazla olduğu önceliktir. Bu destek ve ulusal katkılarla oluşan toplam bütçenin önceliklere göre dağılımı ise, aşağıdaki tabloda yer almaktadır: 
Tablo 1. INTERREG IVC Dönem Bütçesinin Önceliklere Göre Dağılımı

\begin{tabular}{|l|l|l|l|l|l|l|}
\hline & $\begin{array}{c}\text { Toplam } \\
\text { Fon } \\
(\text { Euro })\end{array}$ & $\begin{array}{c}\text { Toplam } \\
\text { Fon Oranı } \\
(\boldsymbol{\%})\end{array}$ & $\begin{array}{c}\text { ABKF } \\
\text { KatkıI } \\
(\text { Euro })\end{array}$ & $\begin{array}{c}\text { ABKF } \\
\text { Katkıs } \\
\text { Oranı } \\
(\%)\end{array}$ & $\begin{array}{c}\text { Ulusal } \\
\text { Katkı } \\
(\text { Euro })\end{array}$ & $\begin{array}{c}\text { Ulusal } \\
\text { Katkı } \\
\text { Oranı } \\
(\%)\end{array}$ \\
\hline $\begin{array}{l}\text { Öncelik 1: } \\
\text { Yenilikçilik ve Bilgi } \\
\text { Ekonomisi }\end{array}$ & $220,908,711$ & 54.53 & $176,726,969$ & 55.00 & $44,181,742$ & 52.74 \\
\hline $\begin{array}{l}\text { Öncelik 2: } \\
\text { Çevre ve Risk } \\
\text { Önleme }\end{array}$ & $156,644,359$ & 38.67 & $125,315,487$ & 39.00 & $31,328,872$ & 37.40 \\
\hline $\begin{array}{l}\text { Öncelik 3: } \\
\text { Teknik Destek }\end{array}$ & $27,541,866$ & 6.80 & $19,279,306$ & 6.00 & $8,262,560$ & 9.86 \\
\hline TOPLAM & $405,094,936$ & 100.00 & $321,321,762$ & 100.00 & $83,773,174$ & 100.00 \\
\hline
\end{tabular}

Kaynak: Interregional Cooperation Programme, 2011: 73.

\section{ESPON Programı}

1998-2000 y1lları arasında INTERREG kapsamında bir pilot program olarak uygulanan Avrupa Mekansal Planlama Çalışma Programı- AMPÇP (Study Programme on European Spatial PlanningSPESP), günümüzdeki ESPON (European Spatial Planning Observation Network- Avrupa Mekansal Planlama İzleme Ağı) programının temelini oluşturmaktadır. ESPON 2006 adıyla 2002-2006 yıllarında ilk dönem uygulaması tamamlanmış, ardından ESPON 2013 adıyla 2007-2013 ikinci dönemine başlanmıştır. INTERREG III kapsamında başlatılmış ve Avrupa Yersel Uyumu Hedefi kapsamında, Bölgesel İşbirliği Programı INTERREG IVC ile birlikte işleyen üç bölgelerarası ağ programından biri olarak sürmüştür. 2014-2020 döneminde ise ESPON 2020 adiyla uygulanmasına karar verilmiştir. Bu program, INTERREG ile birlikte bir mekansal gelişme uygulaması olarak hayata geçirildiğinden, öncelikle ESPON ve mekansal gelişme bağlantısının Avrupa bölgesel/uyum politikaları içindeki gelişimini kısaca değerlendirmek gereklidir. Ardından Programın hukuki temelleri, kapsamı, yapısı ve işleyişi, dönemler dahilinde ele alınacaktır.

\subsection{Mekansal Gelişme ve ESPON'un Temelleri}

Avrupa Mekansal Planlama Çalışma Programı- AMPÇP (Study Programme on European Spatial Planning- SPESP) temelinde bir deneme programıdır. 1980'lerde başlayan ve 1990'lar boyunca tartışılan, 1999 yılında AMGP'nin ilan edilmesiyle somutlaşan uzun bir sürecin parçası olan ESPON'un öncülüdür. 1990'ların sonunda yaşanan sürecin temelinde iki düşünce bulunduğunu ifade etmek mümkündür: Avrupa'da mekansal gelişme konularında uzmanlaşmış araştırma merkezleri arasında bir ağ oluşturmak ve tüm Avrupa'daki mekansal gelişmeyi izlemek için gerekli kriter ve göstergeleri ortaya koyacak güvenilir istatistikler elde etmek. İşte bu düşüncelerin test edilmesi amacıyla, 1998-2000 yıllarında AMPÇP uygulanmıştır. Sonuçlarının olumlu görülmesiyle, ESPON adıyla daha kapsamlı bir program olarak uygulanmasına karar verilmiştir.

1990'larda yaşanan siyasal gelişim sürecinde, mekansal planlama konusunda bilimsel tavsiyelerin önemi göz önünde bulundurulmuş, yersel gelişmenin bilimsel olarak analiz edilmesinin gerekli olduğu gerçeği de değerlendirmeye alınmıştır. Bunun ilk somut yansıması, 1994 Leipzig Bakanlar Toplantısı'nda ulusal mekansal planlama araştırma merkezlerinden oluşan bir ağ yapısında bir Avrupa Mekansal Planlama İzleme Merkezi oluşturulması için bir prensip kararının alınmasıdır. Avrupa bütünleşmenin artmasıyla birlikte, ulusal mekansal planlama araştırmalarının Avrupalılaşması gereği vurgulanarak yapılan bu öneride, bu Avrupa mekansal araştırma ağının amaçları ve görevleri de 
sayılmıştır (BMBau, 1994: 22): Ulusal araştırma merkezlerinin faaliyetleri ve araştırma sonuçlarından elde edilen bilgilerin toplanması ve karşılıklı alış verişine imkan veren bir forum; ortak kazanımlara ilişkin araştırma konularının tanımlanması; sosyal ve ekonomik etki araştırmalarının geliştirilmesi; standart ve yöntemlerin uyumlaştırılması (istatistikler, haritalar, mekansal izleme sistemleri, araştırma yöntemleri); terminoloji ve planlama terimlerinin uyumlaştırılması; mekansal planlamada ekolojik ve sosyal standartların tartışılması; ortak araştırma projelerinin yapılması.

$\mathrm{Bu}$ ağ önerisinin konu açısından önemli olmasının sebebi, gelecekte, bu önerinin 1998-2000 yılları arasında INTERREG kapsamında bir pilot program olarak uygulanan Avrupa Mekansal Planlama Çalışma Programı ve günümüzdeki ESPON (European Spatial Planning Observation NetworkAvrupa Mekansal Planlama İzleme Ağı) programının temelini oluşturmasıdır. Bu önerinin aslında genişleyen ve genişleyecek AB'nin düşünülerek yapıldığını ifade etmek yanlış olmayacaktır. Çünkü beklenen sadece üçüncü ülkelerle ve AB'nin potansiyel üyeleriyle değil, aynı zamanda Akdeniz'in güneyindeki ülkelerle de işbirliği ilişkilerini geliştirmek olmuştur. Kısaca, daha geniş ve izlenebilir bir Avrupa coğrafyası hedeflenmiştir (Caudullo, 2007: 14).Bir pilot eylem olarak Aralık 1998'de başlatılan AMPÇP, ilan edildiği süreçte üç tema çerçevesinde çalışmalarını sürdürmüştür: Avrupa'da yeni bir kır-kent ortaklığı hakkında stratejik bir çalışma programı yürütmek; Avrupa coğrafyasında bileşenler analizi yapmak; Belirlenen ulus ötesi konularda haritalar üretmek. 2 yıllık süreçte 15 üye devletten 200 araştırma merkezinin katıldığı çalışmalar sonucunda, ESPON'un uygulanmasına karar verilmiştir (Study Programme on European Spatial Planning, 2000: 1-2).

\subsection{AMGP Belgesinde ESPON}

AMGP'nin böylesi bir süreçte uygulama ayaklarından biri olarak karşımıza çıkan ESPON'un varlığı, 1999 Potsdam Bakanlar Toplantısı'nın sonuç bildirgesinde de açıkça vurgulanan bir husustur: Gelecekteki ulus ötesi ve bölgelerarası işbirliği için ESPON'un hızlı bir şekilde kurulmasının önemli olduğu karara bağlanmıştır (Final Conclusions, 1999). Kabul edilen AMGP'de de, Avrupa Komisyonu ve Üye Devletler açısından belirlenen ve önerilen bazı eylemler belirtilmiştir (European Commission, 1999: 37-38):

- (167) Avrupa Komisyonu, bazı ortak politikaların mekansal etkilerini sistematik ve periyodik olarak değerlendirmelidir (Ortak Tarım Politikası, Ulaştırma Politikası, Trans-Avrupa Şebekeleri, Çevre Politikası, Rekabet Politikası, Araştırma ve Teknoloji Politikası gibi).

- (170) Topluluk düzeyinde sürekli bir mekansal izleme sistemi gereklidir.

- (171) Avrupa Komisyonu ve Üye Devletlerin, bölgeler ve şehirlerin sürdürülebilir kalkınmasını etkili bir şekilde destekleyebilmesi için, güvenilir kriterler ve göstergeler üzerinde anlaşmaya varmayı gereklidir.

- (172) Mekansal gelişmeye yönelik uzun vadeli senaryoların geliştirilmesi gereklidir.

$\mathrm{Bu}$ önerilerin yerine getirilebilmesi için de, ESPON bir araç olarak kurgulanmıştır. ESPON'un kurumsallaşması önerilmiş ve bir Avrupa Ajansı benzeri yapıda işlevini yerine getirmesi karara bağlanmıştır (European Commission, 1999: 39).

\subsection{Programın Hukuksal Kaynakları}

ESPON'un temelleri iki ana kaynak üzerinden yapılandırılmıştır. İlki, Genel Yapısal Fonlar Tüzüğü'dür (Council Regulation (EC) No 1260/1999). Tüzüğün 20. Maddesi doğrultusunda kurulmas1 öngörülen Topluluk girişimlerinden biri, Interreg olarak belirlenmiştir: Madde 20 (1) (a) Tüm Topluluk topraklarının uyumlu, dengeli ve sürdürülebilir kalkınmasını desteklemeye yönelik sınır ötesi, ulus ötesi ve bölgeler arast işbirliği ('Interreg'). Bu maddeye dayanılarak kurulan INTERREG Programı kapsamında ise, ESPON'un hukuki temelleri oluşturulmuştur. Avrupa'nın uyumlu ve dengeli gelişmesini desteklemek üzere trans-Avrupa işbirliği hakkında bir Topluluk Girişimi olarak düzenlenen INTERREG'in Rehber belgesinin 53. Maddesiyle, bir mekansal izleme merkezinin finansmanı konusunda düzenleme yapılmıştır. ESPON'a ilişkin doğrudan bir atıf bulunmamakla birlikte, belirlenen görevler ışığında, bu madde programın temelini oluşturmaktadır (Communication from The Commission to the Member States (2000/C 143/08)): 
"53. Özellikle Interreg A, B ve C programları kapsamındaki uygulamalarla bağlantılı ă̆ eylemleri yoluyla deneyimlerin ve iyi uygulamaların paylaşılmasını desteklemek için, en fazla 47 milyon Euro pay kullanilacaktır.

Bu kapsamda, Komisyon sınır ötesi, ulus ötesi ve bölgelerarası işbirliği için bir İzleme Merkezi oluşturacaktır. Tamamen Topluluk tarafindan finanse edilecek olan bu Merkez'in görevleri şunlardır:

- Interreg III kapsaminda Topluluk düzeyinde uygulanan eylemlerde, deneyim ve iyi uygulama örneklerinin karşılıklı alış verişi ve koordinasyonunun sağlanması,

- Ortak programlama, izleme ve idare yapılarının oluşturulması ve bütünleştirilmesinin sağlanması, teknik destek verilmesi,

- Komisyon tarafindan bölgelerarası işbirliğine iliş̧kin öneri çağrılarının koordinasyonun yapılması. Kabul edilen projeler ve uygulama bilgilerinin toplanmast,

- Yayınlar yapılması, veri tabanı oluşturulması ve web sitesi kurulması."

$\mathrm{Bu}$ ilgili maddenin yanı sıra, Rehber'e eklenen Komisyon'un ESPON'a İlişkin Açıklaması da, programın yasal temellerinden birini oluşturmaktadır: "15 Üye Devletin, Avrupa çapındaki mekansal gelişme yönelimlerinin izlenmesi ve değerlendirilmesi kapsamında, mekansal gelişme merkezleri arasında bir işbirliği ağı (ESPON) kurma ve finansal bir mekanizma önerisi sunmaları durumunda, Komisyon, Interreg III Rehberi'nin 53. Maddesine yönelik olarak 'ağlar' bütçe başlığı kapsamında bu işbirliğinin ortak finansmanina katılacaktır" (Communication from The Commission to the Member States $(2000 / \mathrm{C} 143 / 08))^{8}$

\subsection{ESPON 2006}

Çeşitli hazırlık çalışmalarının ardından, ESPON 2006 Topluluk Girişimi Programı 12 Temmuz 2001'de Avrupa Komisyonu'na sunulmuştur. 3 Haziran 2002 tarihinde Komisyon'un kabulü üzerine, ESPON 2006 adıyla programın ilk uygulama dönemi başlatılmıştır.

\subsubsection{Programın Amaç ve Hedefleri}

Programın temel amacı, Avrupa düzeyinde yersel gelişme araştırmaları için ortak bir platform ve bilgi temeli oluşturmaktır. Çok yönlü bir hedefler bütünü dahilinde işlemesi planlanan program, çok geniş bir coğrafyaya hitap etmektedir. Detaylı düzenlemelere konu edilmiştir. Öncelikle 7 üst düzey hedef belirlenmiştir (Panteia, 2010: 138):

1. Bir Avrupa boyutu ve ulus ötesi boyut kazandırarak ve Avrupa coğrafyasının farklılıkları ve yersel gelişme anlayışını geliştirerek, var olan ulusal araştırmalara katma değer sağlamak. AB'nin yersel gelişmesi hakkında sonuçlara varabilmek için üye devletlerin yanı sıra aday ülkelerde ve komşu ülkelerdeki yersel yönelimlerin analiz edilmesi de kapsama alınacaktır.

2. AMGP politikasının ulus ötesi ve ulusal alanlardaki etkilerini belirlemek.

3. AMGP politikasının tüm $\mathrm{AB}$ düzeyinden yerel düzeye kadar tüm aktörler tarafından daha iyi algılanması ve uygulanması için gerekli olan araç ve kurumların yönelimlerini geliştirmek.

4. Yapısal Fonların, Uyum Politikasının ve diğer Topluluk politikalarının yanı sıra, ulusal politikaların mekansal boyutunun geliştirilmesi anlayışına katkıda bulunmak.

5. Değişik düzeylerde alınan yersel konularla ilgili kararların koordinasyonunu artırmaya yönelik olarak, somut katkılarda ve önerilerde bulunmak.

6. Karar alıcılar, yöneticiler ve bilim insanları arasında bir köprü oluşturmak.

7. Mekansal gelişme alanında bir Avrupa bilimsel topluluk ağı oluşturmak.

Amaçlara bakıldığında, var olan yöntemler, araçlar ve sonuçlar üzerinden bir Avrupa boyutu oluşturmak isteği görülmekle birlikte, programın bilimsel boyutu yoğun olduğundan ortak yenilikçi

\footnotetext{
${ }^{8}$ Statements on Chapter VII, Statement by the Commission on ESPON.
} 
yöntemlerin ve yaklaşımların da geliştirilmesi ve uygulanması mümkün görülmektedir. Uzun yıllar boyunca birbirinden farklı yöntemler ve araçlar yoluyla mekansal gelişmeyi ele alan aktörler arasındaki bu yöntem farklılıklarının giderilmesi, ESPON'a göre ortak çabalar yoluyla mümkündür. Böylelikle bir Avrupa boyutu oluşturma girişimindedir. Avrupa düzeyinde elde edilen verilerden yapılacak çıkarımlarla da, AB politikalarının yersel boyutlarına etki edilebileceği düşünülmektedir.

\subsubsection{Programın Öncelikleri}

Program için kararlaştırılan hedeflere ulaşılabilmesi için, dört alanda faaliyet önceliği belirlenmiştir (Revised Community Initiative Programme, 2004: 12-13): Tematik projeler (Bölge tipolojileri ve şehirlerin mevcut durumları üzerinden temel mekansal gelişme konuları hakkında projeler); Politika etki projeleri (Ulusal ve $\mathrm{AB}$ politikalarının mekansal etkileri hakkında çok düzeyli projeler); Tematik projelerin koordinasyonu (Bu tür projelerle, yapılmış olan diğer projelerin sonuçları değerlendirilecektir); Bilimsel bilgilendirme ve ağ oluşturma (AB kaynaklarının ve ulusal kaynakların arasında, araştırma ve araştırma kapasitesini geliştirme amacıyla, sinerji oluşturma).

$\mathrm{Bu}$ öncelikler benimsenirken temel yaklaşım, tüm düzeylerde idari yapıların (AB-ulusal-bölgeselyerel) konuya ilişkin sorunlarının ve çözümlerine yönelik uygun önlemlerin belirlenmesi ve geliştirilmesi yönündedir. Program için belirlenen öncelikler, aslında faaliyet alanlarını da işaret etmektedir. Her bir öncelik belirlenirken, doğrudan ESPON amaçlarına yönelik bir görevle bütünleştirilmiştir. Üst düzey hedefler uzun vadeli işbirliği çerçevesine yönelikken, burada ele alacağımız öncelikler ve önlemler, program dahilinde uygulanacak olan projelere yöneliktir. Çok fazla detaya girmeden, aşağıda bir tablo halinde bu öncelik ve önlemler, tasarlanan eylemlerle birlikte gösterilmektedir:

Tablo 2. ESPON 2006 Programı Öncelikleri ve Önlemleri

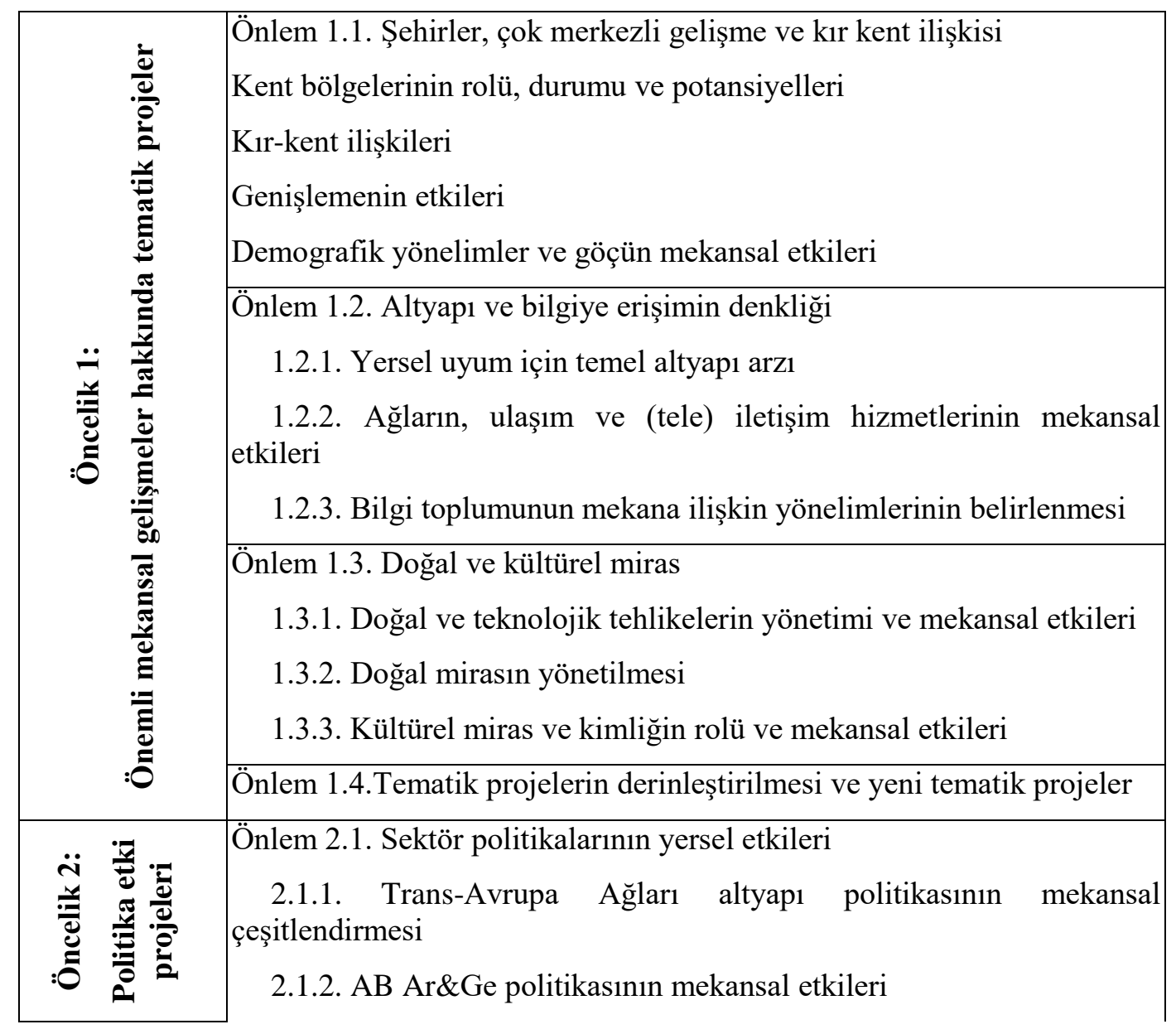




\begin{tabular}{|c|c|}
\hline & $\begin{array}{l}\text { 2.1.3. AB Tarım Politikasının özellikle çevresel boyutta mekansa } \\
\text { etkileri }\end{array}$ \\
\hline & $\begin{array}{l}\text { Önlem 2.2. Yapısal Fonlar ve diğer fonların yeni yersel boyutları } \\
\text { 2.2.1. Yapısal Fonların ve diğer fonların yersel etkileri } \\
\text { 2.2.2. Kent bölgelerinde Yapısal Fonların etkileri }\end{array}$ \\
\hline & \begin{tabular}{|l} 
Önlem 2.3. Mekansal politika araçları ve kurumları \\
2.3.1. Üye devletlerde AMGP'nin uygulanması ve etkileri \\
2.3.2. AB'de yersel ve kent yönelimli politikaların koordinasyonu
\end{tabular} \\
\hline & Önlem 2.4. Politika etki projelerinin derinleştirilmesi ve yeni projeler \\
\hline \multirow{4}{*}{ 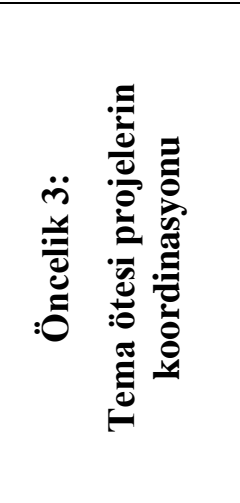 } & Önlem 3.1. Avrupa'nın mekansal gelişmesi için bütünleştirilmiş araçlar \\
\hline & $\begin{array}{l}\text { Önlem 3.2. AMGP ve Uyum politikasına yönelimler ve mekansal } \\
\text { senaryolar }\end{array}$ \\
\hline & Önlem 3.3. Lizbon ve Göteborg süreçlerinin yersel boyutları \\
\hline & $\begin{array}{l}\text { Önlem 3.4. Tema ötesi projelerin derinleştirilmesi ve yeni projeler } \\
\text { 3.4.1. Dünyada Avrupa } \\
\text { 3.4.2. Tema ötesi projelerin derinleştirilmesi } \\
\text { 3.4.3. Yeni projeler }\end{array}$ \\
\hline \multirow{3}{*}{$\begin{array}{l}\text { Öncelik 4: } \\
\text { Bilimsel ağ } \\
\text { kurma }\end{array}$} & Önlem 4.1. Veri seyri: Veri girişi hakkında hazırlık çalışmaları \\
\hline & Önlem 4.2. ESPON İrtibat Noktaları'nın koordinasyonu \\
\hline & Önlem 4.3. ESPON Ulusötesi Proje Grupları'nın koordinasyonu \\
\hline \multirow{2}{*}{$\begin{array}{c}\text { Öncelik 5: } \\
\text { Teknik destek }\end{array}$} & Önlem 5.1. Yönetim, uygulama, izleme ve kontrol \\
\hline & Önlem 5.2. Bilgi, yayın ve değerlendirme \\
\hline
\end{tabular}

Kaynak: Revised Community Initiative Programme, 2004: 16-17.

\subsubsection{Programın Bütçesi}

ESPON 2006 Programında ortak finansman yarı-yarıya usulüyle işlemektedir; \%50 ABKF desteği, $\% 50$ ulusal finansman. Bu doğrultuda, ESPON için 2002-2006 yıllarına ilişkin bir bütçe harcama planı çıkarılmıştır. Toplamda 14.464.688 milyon EURO'luk tahsisatın öngörüldüğg̈ programda, yaklaşık \%30’luk kısım Öncelik 1 kapsamındaki projelere (4.250.000 Euro), \%25'erlik kısımlar Öncelik 2 ve 3 projelerine (3.719.325 Euro - 3.699.500 Euro), yaklaş1k \%8'lik kısım Öncelik 4 faaliyetlerine (1.106.100 Euro) ve son olarak yaklaşık \%12'lik kısım Öncelik 5 faaliyetlerine (1.689.763 Euro) ayrılmıştır. Ayrıca program merkezi olması itibariyle Lüksemburg katkısı adıyla, Teknik Yardım başlığına 2.063.000 Euro daha pay eklenmiştir (Revised Community Initiative Programme, 2004: 12$13)$.

\subsubsection{Programın Çıktıları ve Değerlendirilmesi}

Programın ilk ara dönem değerlendirmesi 2004 yılında yapılmıştır. Henüz 2 yıl geçmiş olması nedeniyle, başlangıcından itibaren atılan somut adımlar, olumlu değerlendirilecek düzeyde olmuştur. Öncelikle programın idari yapısı bütünüyle oluşturulmuş, proje teklifleri öncelikler itibariyle başlatılmıştır. İkinci yılın sonunda Öncelik 1 kapsamında 10 proje belirlenmiş, bunların 8'i uygulanmaya başlanmıştır; Öncelik 2 kapsamında 9 proje belirlenmiş, 6 tanesi uygulanmaya başlanmıştır; Öncelik 3 kapsamında ise 2 proje belirlenmiştir. Öncelik 4'e ilişkin yapılan en belirgin çalışmalardan biri, uygulanan bir proje yoluyla tüm Avrupa'ya ilişkin yerel veri ve harita 
araştırmalarını destekleyecek bir el kitabı hazırlanmasıdır. Ayrıca ESPON İrtibat Noktaları ve Ulusötesi Proje Grupları için de yıllık seminerler ve toplantılar düzenlenmeye başlanmıştır (MVA, 2003: 13-18). Toplanan verilerin ve üretilen bilgilerin sistematik olarak yayınlanması ise, temel olarak kurulan ESPON internet sitesi üzerinden yapılmaya başlanmıştır. ${ }^{9}$ Henüz çalışmalarının başında olması itibariyle, doğrudan $\mathrm{AB}$ teknik politikalarına yön verecek çapta bilgi üretimi mümkün olmamış olmakla birlikte, ilk iki yılda üretilen bilgiler AB'nin Üçüncü Ekonomik ve Sosyal Uyum Raporu'na katkıda bulunmuştur (European Commission, 2004: 32, 77-78). Ayrıca AMGP'nin olumlu ve normatif yönlerine ilişkin konulara odaklanarak, Avrupa'nın mekansal boyutta verilerinin toplanması için çalışmalara ağırlık verilmiştir. 2006 yılına gelindiğinde ise, toplam 30 proje uygulama konulmuş ve bunların 15'i tamamlanmıştır. Elde edilen sonuçlar ve üretilen bilgi bakımından değerlendirildiğinde, ESPON 2006, Topluluk Girişim Programı'nın belirlemiş olduğu hedeflerin çok üzerine çıkmıştır (MVA, 2005: 22-28).

ESPON 2006 döneminde en önemli başarılardan biri ESPON Veri Tabanı'nın oluşturulmaya başlamasıdır. Henüz kurulma aşamasında olmasına rağmen, oldukça kapsamlı bir bilgi bankası sunarak, AB'nin özellikle Bölgesel Politika çalışmalarında zorluk yaratan yerel düzeyde verilere erişme zorluklarına bir çözüm alternatifi oluşturmaya başlamıştır. Özellikle AB'nin kurguladığı NUTS düzeylerinde verilerin toplanması önemlidir. Bu Veri Tabanı, ilk dönemde aşağıdaki araçlardan oluşmaktadır:

- Veri Seyir Aracı (Data Navigator): ${ }^{10}$ Veri Tabanının merkezini oluşturmaktadır. AB ve diğer program ülkelerindeki temel veri kaynakları hakkında bir çerçeve yapı sunmaktadır. ESPON'un uygulamalı araştırmaları için de kaynak olarak kullanılan bu verilere, ulusal ve bölgesel düzeylerde olduğu gibi, $\mathrm{AB}$ ve ulusötesi düzeylerde de ulaşı1ması mümkündür. Veri Seyri Aracı'yla tarım, iletişim teknolojisi, kültür, istihdam, yatırımlar, çevre, altyapı, kentleşme, arazi kullanımı, nüfus, kamu sektörü, Ar\&ge, sosyal yap1, mekansal tipolojiler, iletişim ve bilgi toplumu, turizm, ulaştırma, refah ve üretim alanlarında Avrupa çapında yersel verilerin araştırılması desteklenmektedir.

- ESPON Temel Göstergeleri ${ }^{11}$

- ESPON Proje Göstergeleri ${ }^{12}$

- Hiperatlas ${ }^{13}$

Başka araçların da geliştirilme aşamasına gelindiği ESPON 2006 sürecinin sonunda projelerin kalitesine bakıldığında, farklı düzeylerde başarılar görülmektedir. Bazıları ciddi anlamda ufuk açıcı sonuçlar ortaya koyarken, bazıları yöntem sorunlarıyla karşı karşıya kalmıştır. Projelerde özellikle ilk yıllarda, ekonomik kalkınma konusundan çok mekansal analiz ve planlama konularına ağırlık verilmiştir. Ayrıca Öncelik 2 (Politika etki projeleri) kapsamında gerçekleştirilen projeler, ESPON'un Topluluk politikalarıyla olan ilişkisini de göstermektedir. Bu dönemde yürütülen 10 etki projesinden iki tanesi Trans-Avrupa Ağları, bir tanesi ArGe politikası, bir tanesi tarım politikası, iki tanesi Yapısal Fonlar/Uyum Politikası, bir tanesi katılım öncesi destekler hakkında gerçekleştirilmiştir. Her ne kadar olumlu sonuçlar konulmuş olsa da, ESPON'un Topluluk politikaları üzerinde doğrudan ve ciddi boyutta bir yansıması olduğunu söylemek doğru olmayacaktır. Lizbon stratejisine yönelik çalışmalar da yapılmış olmakla birlikte, doğrudan bir politikaları yönlendirme etkisi ya da yansımaları henüz yoktur (Panteia, 2010: 140).Ancak yine de AB'nin ekonomik ve sosyal uyum değerlendirmelerinde kaynak teşkil etme özelliğinde daha belirgin bir rol yüklenmeye başlanmış, Komisyon'un hazırladığı

\footnotetext{
${ }^{9}$ ESPON Programı Web Sayfasi: http://www.espon.eu/main/ .

${ }^{10}$ Data Navigator bağlantısı (2005 itibariyle): (Çevrimiçi)

http://www.espon.eu/main/Menu_ToolsandMaps/ESPON2006Tools/datanavigator.html 4.5.2011.

${ }^{11}$ ESPON Basic Indicators bağlantısı (2005 itibariyle): (Çevrimiçi)

http://www.espon.eu/main/Menu_ToolsandMaps/ESPON2006Tools/DatabasePublicFiles/basicindicatorsterms.html 4.5.2011.

${ }^{12}$ ESPON Project Indicators bağlantısı (2005 itibariyle): (Çevrimiç) http://www.espon.eu/main/Menu ToolsandMaps/ESPON2006Tools/DatabasePublicFiles/projectindicatorsterms.html 4.5.2011.

${ }^{13}$ Hyperatlas bağlantısı (2007 itibariyle): (Çevrimiç)

http://www.espon.eu/main/Menu_ToolsandMaps/ESPON2006Tools/HyperAtlas/4.5. 2011.
} 
Dördüncü Ekonomik ve Sosyal Uyum Raporu'ndaki analizlerde ESPON çalışmalarıyla elde edilen veriler yoğun olarak kullanılmıştır (European Commission, 2007).

Bununla birlikte, tüm $\mathrm{AB}$ düzeyinde mekansal bir perspektif oluşturması, ortak bir dil geliştirmesi ve politikalarda uygulanabilirlik beklentileriyle kurgulanan program, ilk uygulama dönemi sonunda bazı eleştiriler de almıştır. Bu eleştirileri birkaç noktada toplamak mümkündür (European Commission, 2006: 6-7): Program yaklaşımı ve yönetiminin karmaşık olması; Bilimsel geçerlilik ve kalite güvencesinin belirgin olmaması; Teklif çağrılarında sorunlar yaşanması; Proje idare ve yönetimi sürecinin külfetli olmasi; Tematik kapsamı genel olarak memnuniyet verici düzeyde olmakla birlikte, geliştirilme ihtiyacı duyulması; Uygulamada coğrafi kapsamda alt düzey bölgelerin yeterince ele alınmaması; İletişim, bilginin yayılması ve diğer programlarla bütünleşme konusunda eksikleri olması. $\mathrm{Bu}$ noktada sorun yaratan hususlardan biri de, proje sonuç raporlarının çok fazla teknik ve akademik dilde yayınlanmış olması ve bunlardan yararlanmak isteyen bilimsel dünya dışındaki aktörlerin zorluk yaşamaları, dolayısıyla program çalışmalarından elde edilen sonuçların uygulamaya konulamaması yönünde olmuştur (Panteia, 2010: 139). Bu durumun önüne geçmek için çeşitli çalışmalar yapılarak, sonraki yıllarda daha basit dilde hazırlanan sentez raporları yayınlanmaya başlanmış, konferanslarla bilgi yayılımı süreci desteklenmiş ve seminerler düzenlenmiştir. $\mathrm{AB}$ düzeyinde politika geliştiren bürokratlarla da çeşitli platformlar üzerinden ilişkiler kurulmaya çalışılmış olmakla birlikte, ilk uygulama döneminde ESPON'un hedef grubunun oldukça dar kaldığını belirtmek gereklidir.

\subsection{ESPON 2013}

İlk dönemin sonunda eleştirilen yönlerine rağmen, meydana koyduğu üretimin düzeyi tatminkar bulunduğundan, ilk uygulama döneminin sonuna yaklaşan süreçte, programın 2007 yılı sonrasında da uygulanması talepleri ve istekleri AB düzeyinde Bakanlar tarafından dile getirilmiş ve 2007-2013 dönemi için yenilenmesi destek bulmuştur. ${ }^{14}$ Böylelikle, programın $2007-2013$ döneminde uygulanmaya devam edilmesi mümkün olmuştur. Bu dönemdeki adıyla ESPON 2013, Lizbon sürecinin ve Lizbon Antlaşması'yla üst düzey bir politika olarak kurgulanan ekonomik, sosyal ve yersel uyum kapsamında değerlendirilmiştir. Yine Yapısal Fonlar dahilinde işleyen bir program olarak düzenlenen, bununla birlikte politikaların 'yersel' boyutunda önem verilen program, yenilenen öncelikleri ve eylemleriyle, AB düzeyinde uyum politikasının bir parçası haline getirilmeye çalışılmıştır. Bölgeler arası gelir ve refah dengesizliğinin son genişlemeyle birlikte daha da artmış olması, AB'nin bütün ilgili politika ve araçlarında bir görev birliği yaratırcasına bu sorunları giderme amacına yönelik genel yaklaşımının ortaya konmasına neden olmuştur. O yüzden ESPON 2013 ve bu program döneminde gerçekleştirilen projeler, uygulama sahasında daha fazla uyum politikası izlerini taşımaktadırlar. ESPON 2006 Programı'yla varılan sonuçlara göre, Avrupa coğrafyasının gelişmesinde, uygulanan politikalar neticesinde çok önemli bazı yönelimler ortaya çıkmıştır (ESPON 2013 Programme, 2007: 5-6):

- Piyasa güçleri ve toplumun genel ilerleyişi, faaliyetlerin coğrafi olarak bazı kesimlerde yoğunlaşmasına yol açmaktadır.

- Küresel ekonomik rekabette, $\mathrm{AB}$ bütünleşmesi artarken bölgeler ve bölge üstü alanlar için kendi gelişme yollarını belirlemede yeni yönelimler ortaya çıkmıştır ve bu yönelimlerdeki kilit düşünce şudur: Kalkınma, Avrupa için artık sıfır toplamlı bir oyundur.

- AB ile çevresindeki komşu ülkeler ve dünyanın diğer bölgeleri arasında etkileşim artmaktadır (göç baskısı, nüfus düşüşü, yeni piyasalara giriş ve yatırım, iklim değişimi, Akdeniz ve Karadeniz'de su yönetimi, fosil kaynakları ve boru hatları... gibi konularda).

- Yaşlanan Avrupa nüfusu ve göçler, bölgeleri birbirinden farklı yönlerde etkilemekte ve nitelikli işgücü açısından rekabeti zorlaştırmaktadır.

- İklim değişiminden kaynaklanan riskler artmakta ve Avrupa'nın farklı bölgeleri değişik yönlerden bu riskleri taşımaktadır.

\footnotetext{
${ }^{14}$ Özellikle iki toplantıda yapılan açıklamalar, ESPON'un 2007 sonrasında da uygulanması yönündeki taleplerin öne çıkan örneklerini teşkil etmektedir (Presidency Conclusions, 2004; Presidency Conclusions, 2005).
} 
- Artan enerji fiyatlarının ve ortaya çıkan enerji çıkmazının önemli yersel etkileri bulunmaktadır. Bazı bölgeler diğerlerinden daha fazla etkilenmektedir. Bazı bölgeler de yenilenebilir enerji kaynaklarından üretim yapma potansiyeline sahiptir.

- AB'nin genişlemesi, Birliğin iç uyumuna ve rekabet gücüne yönelik büyük bir sorun teşkil etmektedir.

$\mathrm{Bu}$ yönelimlerle birlikte bir başka sonuç da, yersel sermayenin ve kalkınma potansiyellerinin, Avrupa'nın bir karakteristiği olan bölgesel farklılıkların özünde yer aldığıdır. Yani, bölgelerin farklılıklarının kendileri için değerlendirilmesi gerektiği saptanmıştır. Karşılaştırmalı bölgesel analizler sayesinde, bu Avrupa bölgeleri, Avrupa yersel düzeyinde kendi güçlü ve zayıf yönlerini belirleme ve buna göre kalkınma stratejilerini belirleme firsatını yakalamış olacaklardır (ESPON 2013 Programme, 2007: 8). Bu yüzden ESPON 2006 ile başlayan bilgi temelini geliştirme süreci, 2013 versiyonuyla daha da güçlendirilerek, gelecekteki bölgesel politika temelinde Avrupa yersel boyutuna katkıda bulunmak istendiği görülmektedir. Lizbon ve Göteborg süreçleriyle şekillendirilen yeni dönemde, bölgelerin karşılaştırmalı bilgiler üzerinden kendi kalkınma ve rekabetçilik potansiyellerini görebilmelerine destek olunması isteği de söz konusudur.

\subsubsection{Programın Amacı ve Hedefleri}

Oluşturulan 2007-2013 Uyum Politikası, bölgesel politikaya bir müdahale desteği yoluyla, bölgelerarası uyum, bölgesel rekabetçilik ve Avrupa yersel işbirliğini sağlama amaçlarını göstermektedir. Bu doğrultuda Yapısal Fonlar için yapılan yeni dönem düzenlemesine göre, Genel Yapısal Fonlar Tüzüğü'nün 3. Maddesiyle belirlenen 'Avrupa Yersel Uyumu' hedefi kapsamında Bölgelerarası İşbirliği Ağları'ndan biri olarak ESPON 2013, 7 Kasım 2007 tarihinde başlatılmıştır (Coucil Regulation (EC) No 1083/2006). Özelde, ABKF Tüzüğü’nün 6. Maddesiyle düzenlenen Avrupa Yersel İşbirliği'ne göre, ABKF desteğinin bir bölümü üç genel husus üzerinde yoğunlaşarak bölgesel politikanın geliştirilmesine ayrılacaktır (Regulation (EC) No 1080/2006): Yenilikçilik ve bilgi ekonomisi, çevre ve risk önleme odaklı bölgelerarası işbirliği; En iyi uygulamaların aktifleştirilmesi ve transfer edilmesi yoluyla, deneyimlerin karşılıklı alış verişinin sağlanması; Topluluk içinde kalkınma yönelimlerine ilişkin çalışmalar, izleme ve analizler yapılması, verilerin toplanması.

ESPON 2013, bu hususlardan üçüncüsü kapsamında faaliyetlerini yürütmek üzere kurgulanmıştır. Programın genel amacı şudur: "Yersel dinamikler hakkında karşılaştırmalı bilgiler, veriler, analizler ve senaryolar üreterek ve Avrupa'nın rekabetçiliğine, yersel işbirliğine, sürdürülebilir gelişmesine katkı sağlayan bölgelerin ve daha geniş alanların yersel sermaye ve potansiyellerini ortaya koyarak, Avrupa'nın yersel uyumu ve dengeli kalkınmasına ilişkin politikaları desteklemektir" (ESPON 2013 Programme, 2007: 27). Bu amaca ulaşmada, Program için iki tür hedef hazırlanmıştır. Avrupa düzeyinde sonuçlara ulaşılması düşünülen Genel Hedefler ve operasyonel boyutta kurgulanmış olan Stratejik Hedefler. İkinci grup hedefler, güçlü ve zayıf yönlerin değerlendirilmesi neticesinde detaylı olarak belirlenmiş olan programın uygulanmasına ilişkin hedefleri ifade etmektedir (ESPON 2013 Programme, 2007: 27-28).

Genel Hedefler:Avrupa'nın yersel uyum ve kalkınmasına ilişkin bilgi, kanıt, veri ve göstergeleri geliştirmek; Uygulamalı araştırmalarda politik taleplerin ve AB politikaları uygulamalarının göz önünde bulundurulması; Program sonuçlarının aktif hale getirilmesinde, daha uygulayıcıya yönelik bir yaklaşımın benimsenmesi.

Stratejik Hedefler:Bölgelerin Avrupa kapsamında konumlanmasını sağlayan yersel yönelimlerin izlenmesi ve analiz edilmesi, verilerin toplanması, göstergelerin belirlenmesi ve araştırma çalışmaların sürdürülmesi yoluyla, bölgesel politikanın etkinliğini desteklemek; Avrupa yersel gelişme ve uyum stratejik rehberine ilişkin politik konularda ve ABKF desteklerinden yararlanabilecek bölgelere ilişkin konulara açıklık getirmek; Coğrafi olarak kapsama $\mathrm{AB}$ üye devletleri ve aday ülkeler alınırken, program yararlanıcısı olmayan komşu devletlerin bölgelerinin çok sınırlı olarak kapsama alınması;Başta diğer Yapısal Fonlar eylemleri olmak üzere, diğer Topluluk faaliyet ve politikalarıyla sinerji ve tamamlayıcılık oluşturmak;Farkındalık ve ilgiyi artırmaya yönelik bir iletişim politikası ve ağı oluşturmak;Daha basit bir yönetim yapısı ve mekanizma oluşturmak. 


\subsubsection{Programın Öncelikleri}

$\mathrm{Bu}$ amaç ve hedefler doğrultusunda ESPON 2013, aşağıda belirlenen öncelikler kapsamında gerçekleştirilen bir projeler ve çalışmalar bütünü olarak kurgulanmıştır. Yeni dönem öncelikleri ve temel eylemler özetle şunlardır (ESPON 2013 Programme, 2007: 30-58):

Öncelik 1: Yersel gelişme, rekabet ve uyum konularında uygulamalı araştırmalar

Eylemler:Tematik analizler (yersel potansiyeller ve sorunlar hakkında), yersel yönelimler ve öngörü çalışmaları; AB politikalarının yersel etkileri; Bilgi Destek Sistemi.

Öncelik 2: Uygulayıcı taleplerine yönelik hedef analizler

Eylemler: Bütünleştirilmiş çalışmalar ve tematik analiz; Deneysel ve yenilikçi eylemlere bilgi desteği; Diğer Yapısal Fon programlarına ilişkin ortak eylemler.

Öncelik 3: Bilimsel platform ve araçlar

Eylemler: ESPON Veri Tabanı ve veri oluşturma; Yersel endeksler/göstergeler ve Araçlar; Yersel İzleme Sistemi ve Raporlar; Göstergelerin ve haritaların güncellenmesi için hedef eylemler.

Öncelik 4: Aktifleştirme ve katılım

Eylemler: Medya ve Yayınlar; Avrupa seminerleri ve çalıştaylar; Ulusötesi ă̆ faaliyetleri.

Öncelik 5: Teknik destek, analitik yardım ve iletişim

Eylemler: Teknik destek; Analitik destek; İletişim.

$\mathrm{Bu}$ önceliklerle işleyecek olan programda bu dönemde, merkezi katılımcılar olarak Avrupa Komisyonu ve $\mathrm{AB}$ Üye Devletleri yer alırken, Aday Ülkeler'in gözlemci statüsünde katılmak üzere davet edilmeleri söz konusudur. İlke olarak programın coğrafi kapsamı tüm AB topraklarıdır. Bununla birlikte, daha önceki program döneminde yer almış olan Norveç, İsviçre, İzlanda ve Lihtenştayn'la imzalanacak özel bir anlaşmayla programda yer almaları mümkün olacaktır. Komşu ülkeler ve diğer bölgelerdeki ülkelerle ilgili uygulama çalışmalarına devam edilecektir. Program kapsamında desteklenecek müdahale alanları ise, Yapısal Fonlar Tüzügü’nün uygulama tüzügüü ile belirlenmiş olan alanlarda yapılabilecektir, ki bu 81 Öncelik Kod'lu "Ulusal, bölgesel ve yerel düzeyde kurumsal kapasitenin güçlendirilmesi” başlığıdır (Commission Regulation (EC) No 1828/2006) ${ }^{15}$ ESPON 2013 aracılığıyla iyi politikalar geliştirilmesi ve programın düzenlenmesi, ulusal-bölgesel ve yerel düzeylerde izleme ve kapasite oluşturma mekanizmaları kapsamında finansal desteğin verileceği anlamina gelmektedir.

\subsubsection{Programın Bütçesi}

ABKF desteğinin ESPON'a verilmesinde 'Topluluk içinde kalkınma yönelimlerine ilişkin çalışmalar, izleme ve analizler yapılması, verilerin toplanması' önceliğinin belirlendiği daha önce belirtilmişti. İşte bu noktada, uygulamada yine bu tüzüğün belirlediği yersel kategoriler dikkate alınmıştır (Commission Regulation (EC) No 1828/2006): ${ }^{16}$ ESPON çalışmaları kentler, dağlık bölgeler, adalar, seyrek ve çok seyrek nüfuslu alanlar, kırsal alanlar (dağlık, ada ve seyrek nüfuslu olanlar dışındakiler), eski AB dış sınırında olan bölgeler (2004 genişlemesi öncesi), en uzak bölgeler, ulusötesi işbirliği alanları, sınırötesi işbirliği alanları ve bölgelerarası işbirliği alanları. Program sonunda bu yersel düzeylerde yapılmış olan çalışmalarla elde edilecek bilgilerle, genel uyum politikası desteklerine bilgi temeli sağlanması amaçlanmaktadır.

ESPON 2013 Programı için tahsisi öngörülen yaklaşık 46 milyon Euro'luk bütçede toplam Topluluk ABKF katkı oranı \%75 olmakla birlikte (ABKF desteği 34.033.512 Euro), öncelikler bazında bu oran

\footnotetext{
${ }^{15}$ Annex II: Categorisation of Funds assistance for 2007-2013, Part A: Codes by Dimension, Table1: Codes for the Priority Theme Dimension.

${ }^{16}$ Table3: Codes for the Territorial Dimension.
} 
oldukça değişkenlik göstermektedir. Önceki dönemle karşılaştırıldığında Topluluk desteğinin özellikle Öncelik 1 (uygulamalı araştırmalar) özelinde yoğunlaştığı görülmektedir (17 milyon Euro). Öncelik 5 (teknik ve analitik destek, iletişim) konusunda ise, finansal sorumluluğun büyük oranda ulusal katkılara yüklendiği görülmektedir. Aşağıdaki tabloda programın mali destek dağılımı, öncelikler ve katkı kaynakları bazında yer almaktadır.

Tablo 3. ESPON 2013 Programı Bütçe Tahsisatı (2007-2013)

\begin{tabular}{|l|l|l|l|l|}
\hline \multicolumn{1}{|c|}{ Öncelik } & \multicolumn{1}{|c|}{$\begin{array}{c}\text { Toplam Fon } \\
\text { Bütçesi (Euro) }\end{array}$} & $\begin{array}{c}\text { Topluluk } \\
\text { Desteği } \\
\text { ABKF (Euro) }\end{array}$ & $\begin{array}{c}\text { Ulusal Katkı } \\
\text { (Euro) }\end{array}$ & $\begin{array}{c}\text { Topluluk } \\
\text { Destek Oranı }\end{array}$ \\
\hline Öncelik 1 & $19.241 .512,00$ & 17.317 .512 & 1.924 .000 & $\% 90$ \\
\hline Öncelik 2 & $6.536 .250,00$ & 5.229 .000 & 1.307 .250 & $\% 80$ \\
\hline Öncelik 3 & $6.148 .000,00$ & 5.225 .500 & 922.500 & $\% 85$ \\
\hline Öncelik 4 & $5.514 .100,00$ & 4.356 .000 & 1.158 .100 & $\% 79$ \\
\hline Öncelik 5 & $7.938 .150,00$ & 1.905 .500 & 6.032 .650 & $\% 24$ \\
\hline TOPLAM & $45.378 .012,00$ & 34.033 .512 & 11.344 .500 & $\% 75$ \\
\hline
\end{tabular}

Kaynak: ESPON 2013 Programme, 2007: 62.

\subsubsection{Programın Çıktıları ve Değerlendirilmesi}

Bir önceki dönemde başlatılan araçlar ve veri tabanları, yeni versiyonlar halinde yükseltilip güncellenerek ve yenileri eklenerek bu program döneminin ürünlerini oluşturmaktadır. Programın Öncelik 3 kapsamında uygulanan 10 bilimsel platform ve araç projesiyle oluşturulan ve sürdürülen ESPON 2013 döneminin temel araçları şunlardır:

- ESPON 2013 Veri Tabanı: ${ }^{17}$ Önceki program döneminde özellikle ağır akademik ve teknik dili nedeniyle eleştirilen bu araç, yeni versiyonda iki kullanım yönlü olarak hazırlanmıştır. Hem $\mathrm{AB} / \mathrm{ulusal} /$ yerel düzeydeki karar alıcılar için hem de bilim insanları için ayrı kullanım alanı oluşturulmuştur. Veri Tabanındaki veriler iki tür kaynaktan sağlanmaktadır: Eurostat ve ESPON Proje sonuçları. Bölgesel, yerel, kent, aday ülkeler ve dünya çapında kategorilerde bilgiler üretilmiştir. NUTS sistemiyle uyumlu düzeylerde bu bilgiler paylaşılmaktadır. Ayrıca veri kategorilerini açıklayan ve araştırmacılara yardımcı olmak üzere hazırlanan teknik raporlar da yer almaktadır. Veri Tabanında bulunan araştırma temaları itibariyle, henüz hepsi \%100 tamamlanmış değildir. Projelerin ele aldığı bölgeler için daha fazla veri üretilmesi mümkünken, projelere konu edilmeyen ya da kısıtlı ele alınan yersel kategoriler hakkında, daha çok zaten var olan veriler sunulabilmektedir. Burada ulusal veri kaynakları gündeme gelmektedir. Ulusal veri toplama ve yayınlama düzeyi de göz önünde bulundurulması gereken bir husustur.

- Online Harita Bulma: ${ }^{18}$ Tematik haritaların indirilebildiği, karşılaştırma yapmaya imkan veren bir araçtır.

- Hiperatlas: ${ }^{19}$ Yeni versiyonuyla bölgeler hakkında detaylı bilgi içeren, anında yerel/bölgesel/ulusal ve $A B$ düzeyinde karşılaştırmalı bilgi elde edilebilecek bir araçtır.

\footnotetext{
${ }^{17}$ Veri tabanında aday ülkelere ilişkin bilgiler özelinde Türkiye NUTS Düzey 1,2 ve 3 hakkında da temel bilgilerin kaynakları yer almaktadır. Eurostat ve TÜİK verileri kullanılmaktadır. ESPON 2013 Database bağlantısı (Çevrimiçi) http://www.espon.eu/main/Menu_ToolsandMaps/ESPON2013Database/ 3.5.2013.

${ }^{18}$ ESPON Online Map Finder bağlantısı (Çevrimiçi)

http://www.espon.eu/main/Menu_ToolsandMaps/OnlineMapFinder/ 3.5.2013.

${ }^{19}$ ESPON HyperAtlas bağlantısı (Çevrimiçi)

http://www.espon.eu/main/Menu_ToolsandMaps/ESPONHyperAtlas/ 3.5.2013.
} 
- Veri Seyir Aracı: $:^{20}$ Farklı bölgesel düzeylerde yersel bilgi kaynaklarına konular itibariyle nasıl erişilebileceğini gösteren bir araçtır.

- ESPON Tipolojileri: ${ }^{21}$ ESPON 2013 ve sonrası çalışmalarda, hakkında bilgi ve veri üretilecek bölge tiplerini ifade etmektedir. Analitik amaçlarla Uyum Politikasına uygun şekilde belirlenen bu tipler: Kent-kır, metropol bölgeler, sınır bölgeleri, ada bölgeleri, seyrek nüfuslu bölgeler, en uzak bölgeler, dağlık bölgeler, kıyı bölgeleri, sanayi geçiş bölgeleridir.

Program döneminde gerçekleştirilen proje sayısı toplam 81'dir. $\mathrm{Bu}$ projelerin bir bölümü tamamlanmış, bir bölümü ise uygulanmaya devam etmektedir. Uygulamaya devam eden projelerin büyük bölümü, Programın sürdürülebilirliğini sağlamak üzere kurgulanan projelerdir. Son olarak, öncelikler kapsamında bazı projeler şunlardır (ESPON, 2012): ${ }^{22}$

Öncelik 1 Projeleri: 25 Uygulamalı Araştırma Projesi hazırlanmıştır. Tematik konularda hazırlanan bu projeleri Avrupa yersel yönelimleri, öngörüler ve politika etkileri hakkında bilgiler üretmektedir. Temalara ve projelerin kapsamına ilişkin bir fikir oluşturması bakımından, iki Öncelik 1projesi şunlardır: Şehirler İçin Gelecek Fırsatları (Future Orientations for Cities- FOCI); 2011 yılında tamamlanan ve yaklaşık 1 milyon Euro bütçeye sahip olan bu projeyle, Avrupa kentsel sisteminde büyük şehirlerin gelişme fırsatları araştırılmıştır. Avrupa'da İkincil Büyüme Kutupları ve Yersel Gelişme; Performans, Politikalar ve Beklentiler (Secondary Growth Poles and Territorial Development in Europe; Performance, Policies and Prospects- SGPTD); 2012 y1lında tamamlanan ve 745 bin Euro'luk bütçeye sahip olan 3 ülkeli projeyle, özellikle başkent şehirleriyle karşılaştırıldığında ikincil büyüme kutupları olan bölgelerin gelişmesinin avantajlarının neler olabileceği araştırılmıştır.

Öncelik 2 Projeleri: 23 Hedef Analiz Projesi hazırlanmıştır. Ulusal, bölgesel ve yerel paydaşların kendi bölgelerinin durumunu ve Avrupa perspektifini daha iyi anlamaları ve öğrenmeleri için talepleri üzerine hazırlanan projelerdir. Bu Öncelik kapsamındaki iki proje örneği şunlardır: Uyum Bölgeleri Ekonomileri İçin Başarı ( Success for Convergence Regions' Economies- SURE); Uyum bölgeleri hakkında hazırlanan 2011 yılında tamamlanmış ve 200 bin Euro bütçeye sahip bu 6 ülkeli proje, AB içindeki tüm uyum bölgelerine ilişkin ortak özellikleri ve belirleyici faktörleri tespit etmeye ilişkin bir hedef analizdir. Avrupa Metropollerinde En İyi Gelişme Koşulları: Paris, Berlin ve Varşova (Best Development Conditions in European Metropolises: Paris, Berlin and Warsaw- BEST METROPOLISES); Metropol bölgelere ilişkin bu proje 2013 yılında tamamlanmıştır ve yaklaşı 350 bin Euro bütçeye sahiptir. Paris, Berlin ve Varşova örneklerinde metropolleşme sürecinin özellikle yaşam şartları, dolaşım ve yönetim üzerindeki etkilerine ilişkin sonuçları belirlemiştir.

Öncelik 3 Projeleri: ESPON Araçlarının ve bilimsel yapısının uygulanmasına ilişkin 10 büyük proje gerçekleştirilmiştir. Programın bilimsel platformunu sürdürmeye yönelik projelerdir: ESPON Veri Tabanı Aşama I (ESPON Database 2013Phase I), ESPON Tipoloji Derlemesi (ESPON Typology Compilation), ESPON Hiperatlas Güncellemesi (Update of the ESPON HyperAtlas), AB Yersel İzleme Sistemi (EU Territorial Monitoring System) gibi.

Öncelik 4 Projeleri: 7 Ağ Faaliyeti Projesi gerçekleştirilmiştir. Yersel stratejiler, ulusötesi perspektifler, yersel boyutlar ve kavramlar, e-öğrenme, mikro bölgesel perspektif gibi konular ele alınmıştır: Bütünleştirilmiş Yersel Stratejilerde ESPON (ESPON in Integrated Territorial Strategies ESPON INTERSTRAT), ESPON Kavramlarının Aktifleștirilmesi ve Yayılması (Capitalisation and Dissemination of ESPON Concepts- CADEC) ve ESPON Kuzey Avrupa Bulguları (ESPON ESPON Evidence in a North European Context - ENECON) örnek projeler olarak sayllabilir.

Programın temel amacını ifade eden veri toplama, bilgi üretme, bu bilgiyi yayma ve uygulama alanında uyum politikasına destek oluşturarak bir bilgi altyapısına katkıda bulunma hedefleriyle geliştirilen araçlar, daha olgunlaşmış bir veri sistemi şeklinde görünmektedir. Dönem başında programa yönelik eleştirilerin göz önünde bulundurulmasıyla, daha sade dille ve yerel yönetimlerin de

\footnotetext{
${ }^{20}$ ESPON Data Navigator bağlantısı (Çevrimiçi)

http://www.espon.eu/main/Menu_ToolsandMaps/ESPONHyperAtlas/ 3.5.2013.

${ }^{21}$ ESPON Regional Typologies bağlantısı (Çevrimiçi)

http://www.espon.eu/main/Menu_ToolsandMaps/ESPONTypologies/ 3.5.2013.

${ }^{22}$ Tüm ESPON projelerinin hakkında kendi web sayfaları ve yayınları üzerinden bilgi almak mümkündür. Projeler hakkında verdiğimiz bilgilerin tümü, ESPON 2013 Projeler yayınından derlenmiştir.
} 
uygulamada dikkate alabileceği, teknik dilden arındırılmış sonuçlar yayınlanmasına da dikkat edilmiştir. Bununla birlikte bilgi toplama süreci henüz tamamlanmış değildir.

\section{2014-2020 Döneminde Programlar}

2010 yılında başlatılan 'Avrupa 2020: Akı1lı, Sürdürülebilir ve Kapsayıcı Büyüme Stratejisi’yle, 2020 yılına kadar belirlenen hedeflere ulaşılması amacıyla, bu Stratejiyle uyumlu bir işleyiş dönemi de başlatılmış bulunmaktadır. Önceki dönemde Avrupa Yersel İşbirliği Hedefi olarak uygulanan INTERREG IVC Programı, yeni dönemde INTERREG Avrupa adıyla, Uyum Politikası araçlarından biri olarak sürdürülecekken, ESPON yeni dönemde ESPON 2020 adıyla sürdürülecektir. Yeni Strateji'nin programlara etki alanını Bölgese1/Uyum Politikası bağlamında kısaca değerlendirmek ve henüz kesin ve detaylı içerikleri henüz yayınlanmamış olan programların, 2014-2020 dönemindeki genel anlayışları hakkında kısa bir ön bilgi vermek gereklidir.

\subsection{Avrupa 2020 Stratejisi ve Bölgesel Politika}

Kısaca Avrupa 2020 olarak anılan ve 21. yüzyıl için Avrupa'nın sosyal piyasa ekonomisi vizyonu oluşturduğu ifade edilen bu yeni stratejiyle, Lizbon'la başlatılan büyüme ve istihdam süreci devam ettirilmekle birlikte, yeni öncelik tanımları ve hedefler ortaya konmuştur: Akıllı büyüme (bilgi ve yenilikçilik temelli bir ekonomi geliştirmek); Sürdürülebilir büyüme (kaynakları daha etkin, daha çevreye duyarlı ve daha rekabetçi bir ekonomi geliştirmek; Kapsayıcı büyüme (sosyal ve bölgesel uyumu sağlayacak yüksek istihdama sahip bir ekonomi geliştirmek) (Communication from the Commission COM (2010) 2020). Bu kapsamda yeni Strateji'yle uyumlu bir yapi amaciyla, Uyum Politikası/Bölgesel Politika ve Yapısal Fonlar'da reforma gidilmiştir. Yapısal ve Yatırım Fonları adıyla yeniden bütünleştirilen ve revize edilen fonlar yoluyla (Regulation (EU) No 1303/2013), yeni stratejinin büyüme ve iş yaratma odağına uygun şekilde $\mathrm{AB}$ düzeyinde büyümenin sağlanması ve daha fazla iş yaratılması için, $\mathrm{AB}$ yatırımlarının bölgelerdeki etkinliğinin en üst düzeyde gerçekleştirilmesi amaçlanmaktadır.

$\mathrm{Bu}$ doğrultuda, Bölgesel Politika kapsamındaki desteklerden faydalanma kuralları ve yöntemlerinde ciddi bir kurallar bütünü oluşturulmuş, fonların öncelikli kullanım hedefleri belirlenmiştir: Araştırma ve yenilikçilik, BİT, KOBİ'lerin rekabet gücünün artırılması, düşük karbon ekonomisi (European Commission, 2014: 13). Bunların yanı sıra, istihdam ve hareketlilik, eğitim, sosyal dahil etme ve kamu yönetimi alanlarında da sosyal fon desteği önceliklendirilmiştir. 2014-2020 dönemi toplam AB bütçesinin (1 082 milyar Euro) \%32,5'i (351.8 milyar Euro) Uyum Politikası'na ayrılmıştır ve bu miktarın 182 milyar Euro'dan fazlası en az gelişmiş bölgelere yönlendirilecektir (European Commission, 2014: 3). Bölgelerin ve şehirlerin merkeze alındığı bu dönemde, tek bir reçetenin tüm bölgeler için geçerli olduğu eski anlayış terk edilerek, her bir bölgenin kendi dinamikleri ve ihtiyaçlarının da dikkate alınacağı bir yatııım fonlaması anlayışına gidilmiştir. Her bir bölgenin ve şehrin kendi dinamiklerinin de değerlendirmeye alınması anlayışı, mekansal perspektifin gittikçe yerleşen bir konuma geldiğinin de bir göstergesidir. Bu kapsamda 2014-2020 dönemi için INTERREG Avrupa ve ESPON 2020 olarak karşımıza çıkacak yeni program dönemlerinin ne yönde ilerleyeceği, proje uygulamalarının dönem sonunda ne gibi sonuçlar doğuracağı beklentileri de dolayısıyla dikkate alınmalıdır.

\subsection{INTERREG Avrupa ve ESPON 2020}

AB'nin 2014-2020 dönemi için oldukça geniş katılıma açık bir Genel İstişare süreciyle başlattığ1 program hazırlık çalışmaları, yeni mali dönemin ilk yılı içinde gerçekleştirilmektedir. Avrupa Komisyonu, programların açık olduğu tüm ülkeler ve bölgesel düzeyde aktörlerin görüş alış verişi yoluyla sürdürülen istişare süreci ve elde edilen sonuçların programların uygulama belgelerine aktarılması devam etmektedir. Dolayısıyla programların kesin ve detaylı içerikleri henüz belirlenmemiş olmakla birlikte, genel anlayışları hakkında kısa bir değerlendirme yapılması mümkün olmaktadır. En belirgin ilk ortak husus ise, Avrupa 2020 Stratejisi’nin üç temel ayağı olan akıllı, 
sürdürülebilir ve kapsayıcı büyüme anlayışının Uyum/Bölgesel Politika yoluyla, programların amaç ve önceliklerine de doğrudan uygulanmasıdır. Belirli ve sınırlı sayıda hedefler üzerine odaklı bir yapısal yatırım desteği ve daha kalıcı ve etkin sonuçlar beklentisi söz konusudur

$28 \mathrm{AB}$ üyesi ile programın ortak ülkeleri olan İsviçre ve Norveç’in tüm bölgelerine açı olan INTERREG Avrupa programı, ABKF'ndan 359 milyon Euro desteğe sahip olacaktır (Commission Implementing Decision (2014/366/EU)). Ulusal katkılarla birlikte toplam 426 milyon Euro'luk bütçe belirlenmiştir (Interreg Europe 2014-2020, 2014: 67). Avrupa 2020 Stratejisi'ne uyumlu şekilde belirlenen tematik amaçları araştırma, teknolojik gelişme ve yenilikçilik; KOBI'lerin rekabetçiliğinin güçlendirilmesi; tüm sektörlerde düşük karbon ekonomisine geçişin sağlanması; çevrenin korunması ve kaynak etkinliğinin geliştirilmesidir. Bu doğrultuda programın genel amacı ve kapsamı ise "Tüm $A B$ 'de büyümenin sağlanması ve daha fazla iş yaratılması için yatırım yapılmasının yanı sıra, gerekli durumlarda Avrupa yersel işbirliği amaçlarına da yönelik olarak, ilgili bölgesel aktörler arasında deneyimlerin paylaşılması ve karşıllıkl öğrenme süreçlerinin geliştirilmesi yoluyla, bölgesel gelişmeye yönelik politika ve programların uygulanması"dır (Interreg Europe 2014-2020, 2014: 12-13). Önceki program döneminde gerçekleştirilen sağlam proje sonuçlarının iyi uygulamalar olarak bilgilerinin paylaşılması, yerel yönetim başta olmak üzere tüm bölge aktörlerinin karşllıklı öğrenme süreçleriyle bölgesel deneyimlerin yayılması, temel yönelim olarak belirginleşmiştir. Tüm program deneyimleri gibi, AB, INTERREG Avrupa için de sıkı bir izleme ve kontrol süreci öngörmekte, paydaşların program ve proje süreçlerinde aktif olarak yer almasını talep etmektedir. Fonların etkin ve etkili sonuçlar yaratacak şekilde verimli kullanılmasını garantiye alma amacı bu dönemde daha fazla göze çarpmaktadır.

ESPON 2020, Avrupa 2020 Stratejisi'ne katkıda bulunacak şekilde organize edilmesi istenen ve ayrıca ekonomik, sosyal ve yersel uyumu sağlamak için destek verecek bir işbirliği programı olarak kurgulanmaktadır. Avrupa Yersel İşbirliği amacının gerçekleştirilmesine yönelik olarak ABKF’ndan sağlanacak olan fon kapsamında finanse edilmektedir; toplam 51 milyon Euro'luk bütçesi hesaplanan programın AB'den alacağı destek miktarı 41 milyon Euro'dur (Commission Implementing Decision (2014/366/EU)). Kalan 10 milyon Euro'luk katkı ise, programın açık olduğu 28 AB üyesi ile birlikte 4 ortak ülke olan İzlanda, Lihtenştayn, Norveç ve İsviçre tarafından sağlanacaktır (Espon 2020, 2014: 43-44). Özelde, Strateji'de ortaya konan 'kamu yöneticilerinin ve paydaşların kurumsal kapasitelerini güçlendirmek kamu yönetiminde etkinliği artırmak' tematik amacını benimsemiş olan ESPON 2020, Ayrupa Yersel İşbirliği kapsamında kısaca 'pan Avrupa düzeyinde yersel bulguları toplamak, bu bulguları paylaşılabilir bilgiye dönüştürmek, bölgeler-devletler ve $\mathrm{AB}$ düzeyinde paylaşılmasını sağlamak ve böylelikle kamu yöneticileri ve yerel-bölgesel düzeyde tüm aktörlere yönelik uygulanabilir bölgesel gelişme programları için destek vermek' amaçlarıyla uygulanacaktır. Bu genel amaca yönelik olarak belirlenen yatırım öncelikleri ise şunlardır: Avrupa çapında yersel bulgu ve veri üretiminin devam etmesi; üretilen bu verilerin kullanıcılarına yönelik analitik destek ve bilgi transferi; analiz araçları ve yersel izleme tekniklerinin geliştirilmesi; yersel bulguların daha geniş alanda kullanılması ve hizmete sunulması; daha yalın, etkin ve verimli uygulama hükümleri oluşturmak (Espon 2020, 2014: 15-16).

ESPON 2013 uygulamalarının ve yeni beklentilerin değerlendirilmesiyle, yeni program döneminde odak noktasının daha çok uygulanabilir bilgi üretimi ve bu bilginin uygulayıcı taraflarla karşılıklı olarak daha fazla paylaşılması konusuna yöneldiği görülmektedir. Önceki dönemin eleştirilen yönlerinden biri, üretilen verilerin kamu yöneticileri ve diğer aktörler tarafindan bölgesel gelişme politikaları geliştirmek ve uygulamak için çok fazla bilimsel ve teknik olarak yayınlandığı konusu olmuştur. $\mathrm{Bu}$ eksikliğin giderilmesi için, yeni dönemde programın daha yalın ve anlaşılabilir, böylelikle de hayata geçirilebilir politikalara temel oluşturabilecek bilgi üretimi anlayışının benimsendiği ortadadır. Ayrıca diğer bir önemli güncellik, pan-Avrupa anlayışının daha fazla vurgulanmasıdır. $\mathrm{AB}$ bölgelerinin dışında, $\mathrm{AB}$ sınırdaşı bölgelerin de katılımının artırılması, bu bölgelerin daha kapsayıcı bir anlayışla programda coğrafi kapsama alınması, AB'nin tüm Avrupa coğrafyasının sosyal ve ekonomik gelişmelerini uyumlu bir takip sistemiyle ele almak isteğini yansıtmaktadır. Bölgelerin işbirliği programlarıla ortak politikalar uygulayabilmeleri için, tüm bölgeler hakkında ortak temelde bir veri toplama ve takip anlayışının benimsenmesi, diğer $\mathrm{AB}$ politikalarının da uygulanması, uygulama sonuçlarının ölçülebilmesi için gereklidir. 


\section{Türkiye ve Programlar}

Türkiye, $\mathrm{AB}$ tam üyesi olmadığından Yapısal Fonların (günümüzde Yapısal ve Yatırım Fonları) yararlanıcısı değildir. Tüm aday ülkeler gibi, Katılım Öncesi Mali Yardım Aracı (IPA-Instrument for Pre-Accession) kapsamında finansal destek almaktadır. ${ }^{23}$ İçinde bulunulan katılım müzakereleri sürecinde, Bölgesel Politika ve Yapısal Araçların Koordinasyonu (Fasıl 22) konusunda da çalışmalar yapılmaktadır. 5 Kasım 2013 tarihinde müzakereye açılan bu fasıl kapsamında, Yapısal Fonlara'a ilişkin mevzuatın doğrudan uyumlaştırılması gerekmemekte, fonlarla ilgili tüzüklerde yer verilen ilke ve mekanizmalar yoluyla bu fonların etkin bir şekilde kullanılmasını mümkün kılacak idari ve hukuki düzenlemelerin yapılması beklenmektedir.

Doğrudan Yapısal Fonlar'dan desteklenen Uyum/Bölgesel Politikası'nın fonlar dışı araçlarından olan Interreg ve Espon Programları (ABKF destekli), diğer programlar gibi ilke olarak temelde AB tam üyelerine açıktır. Ancak programların yönetimlerinin uygun bulması durumunda Ortak Ülkelerin katılıma davet edilmesi söz konusu olmaktadır. Bu ülkeler yapılan özel bir anlaşma ile katılmakta, katk1 paylarını kendi kaynaklarından ödemektedirler. 28 AB üyesi devlete ek olarak, Interreg Avrupa'nın Ortak Ülkeleri Norveç ve İsviçre, Espon 2020’nin Ortak Ülkeleri ise İzlanda, Lihtenştayn, Norveç ve İsviçre'dir. Aday ülkeler, Espon Programına gözlemci statüsünde katılabilmektedirler.

$\mathrm{Bu}$ tür bölgesel işbirliği programları kapsamında gerçekleştirilen projeler, benzer özellikler gösteren bölgelerin gelişme dinamiklerini değerlendirmeleri bakımından örnek teşkil etmektedirler. Türkiye tam üyelik müzakereleri kapsamında Bölgesel Politika konusunda ciddi adımlar atmakla yükümlüdür. $\mathrm{Bu}$ konu, AB'nin içinde en fazla tartışılagelen konulardan biridir. Çünkü bölgeler arası gelişmişlik farkları bakımından $\mathrm{AB}$ ortalamasının oldukça altında özellikler sergileyen bölgelere sahip bir aday ülke olarak, tam üyelik durumunda Yapısal Fonlar'dan alması muhtemel destek miktarının yüksekliği senaryoları hakkında tartışmalar yapılmaktadır (Akşahin, 2004: 136-137; DPT, 2004: 32-33; Derviş vd., 2004). Mevcut üye devletlerin aldıkları payın düşmesine neden olacak yoğun bölgesel geri kalmışlık durumu hakkında çok çalışması gereken bir ülke olarak, Türkiye'nin özellikle bölgesel analiz yapma sürecinde veri oluşturma ve olası gelişme senaryoları üretebilme yeteneğini geliştirmesi gerekir ki, ESPON proje uygulamaları bu konuda ciddi örnek teşkil etmektedir. Türkiye'nin Yapısal Fonlar'a hazırlanma süreci gerçeği dışında dahi, bu tür modern ve verimli tekniklerin örneklerini inceleyerek kendi sistemiyle sentezleyebilmesi ve uygulamaya koyabilmesi, ülkenin bütüncül kalkınma politikaları üretebilmesi açısından önemlidir.

Bir diğer konu ise, ESPON bulgularıyla üretilen sonuçların değerlendirilmesi yoluyla yapılan yersel analizlerin, yeni dönem Avrupa Yapısal ve Yatırım Fonları desteğiyle daha etkin program ve projeler üretilmesi için gerekli yatırımlarda dikkate alınmasıdır. Bu kapsamda Fonlar'a hazırlık sürecinde olan Türkiye'de ulusal ve bölgesel yatırım yönlendirme aşamasında, hakkında varılan sonuçların göz önünde bulundurulması da verimli sonuçlar doğuracaktır. ESPON'un elde ettiği yersel bulgular ışında Türkiye'nin durumuna ilişkin tespitlerden birkaç örnek verilebilir (Espon 2020 Draft Programme, 2014: 11, 25, 37-38, 57): - Türkiye'nin çok sayıda bölgesi, her düzeyde eğitimin geliştirilmesine yönelik önlemlerin artırılması gereken bölgeler olarak tespit edilmiştir. - Bilgi ve iletişim teknolojilerinin kullanımı konusunda da Yunanistan, Romanya ve Hirvatistan'la birlikte kırsal bölgelerinde BİT sektörlerinde istihdamın neredeyse hiç olmadığı ülke olarak sayılmaktadır. - Düşük karbon ekonomisine geçiş konusundaki unsurlardan biri olan sera gazı emisyonları kapsamında ise, Türkiye, 1990'lardan itibaren en fazla emisyon artış oranına sahip ülke olarak öne çıkmaktadır. - Bir başka önemli konu olan deniz taşımacılığı konusunda ise, Rusya, Ukrayna ve Kuzey Afrika'yla birlikte kısa mesafe deniz taşımacılığı talebini artıracağı yönde düşünülen gelişmelere sahip bir ülke olma önemine sahiptir. Çok önemli bir başka tespit ise, Avrupa 2020 hedeflerinden biri olan aktif nüfusun \%75'inin istihdamının sağlanması hedefine en uzak bölgelerin yer aldığı ülkelerden biridir

\footnotetext{
${ }^{23} 11$ Temmuz 2008 tarihinde imzalanan "Türkiye Cumhuriyeti Hükümeti ve Avrupa Toplulukları Komisyonu Arasında Katılım Öncesi Yardım Aracı ile Temin Edilen Yardımın Uygulanması Çerçevesinde Türkiye Cumhuriyetine Sağlanan Avrupa Topluluğu Mali Yardımlarıyla İlgili İşbirliği Kuralları Hakkında Çerçeve Anlaşma”, 24 Aralık 2008 tarihinde yürürlüğe girmiş̧tir. 19.12.2008 Tarih ve 200/14450 Sayılı Millletlerarası Andlaşma Kararı, Resmi Gazete tarihi 24.12.2008, say1 27090- Mükerrer.
} 
(Espon 2020 Draft Programme, 2014: 65). İşte bu gibi yersel değerlendirme sonuçları, ESPON'u, ülkenin gelişme ihtiyacı duyulan yönlerinin tespitinde çok yönlü bir değerlendirme alternatifi sunma açısından önemli kılmaktadır. Araştırmacılardan karar alıcılara kadar her düzeyde bilgi kaynağı olarak kullanılabilir.

\section{Sonuç}

1990'lı yılların sonuna ilerleyen süreçte, AB, Yapısal Fonlarla desteklenen bölgesel işbirliğinin bölgelerarası dengesizlikleri gidermede yeterli olmadığını görerek, bir geçiş aşamasına doğru ilerlemeye başlamıştır. AMGP'yle, mekansal boyutta da desteklenmesi düşünülen bu geçişte yersel işbirliğiyle bazı çözümlerin getirilmesi öngörülmüştür. Ancak bu düşünceler hemen uygulamaya konmamış, 2000-2006 dönemi, bir geçiş dönemi olarak kurgulanmıştır. Daha önce başlatılmış olan Interreg Programı'nın üçüncü dönemi (INTERREG III) böylesi bir geçiş döneminde başlatılmış ve uygulanmıştır. 2007-2013 dönemi oluşturulan yeni sistemde belirlenen üç Topluluk hedefinden (Yakınsama Hedefi, Bölgesel Rekabetçilik ve İstihdam Hedefi, Avrupa Yersel İşbirliği Hedefi) Avrupa Yersel İşbirliği, önceki INTERREG III Topluluk Girişimi'nin devamı niteliğinde düzenlenmiştir. Böylelikle AB Bölgesel Politikasında mekansal boyutun daha üst bir bakışla ele alındığ1 görülmektedir. 2014-2020 döneminde INTERREG ve ESPON Programlarının sürdürülecek olması, AB için geçmişte verimli sonuçlar alındığı ve ilerleme yolunda uygun adımlar olarak görüldüğü anlamına gelmektedir.

Ayrıca Avrupa 2020 Stratejisi doğrultusunda, AB'nin gittikçe çözümsüzleşen bölgeler aras1 gelişmişlik farklarını, bölgelerde daha fazla iş yaratma yoluyla azaltarak, topyekün büyümeye katkıda bulunma amacı anlaşılmaktadır. Ayrıca önceki dönemlerde bölgelere verilen fonlar yoluyla yapılan uygulamaların somut sonuçlarının beklentilerin altında olması, bu yeni dönemde tematik olarak daha konsantre ve izleme sürecinin daha sıkı olduğu bir anlayış göze çarpmaktadır. Alt metinde yatan kaygıda, herhangi bir olası kriz durumunda bölgesel bazda Avrupa dahilinde daha dirençli ve kendini savunabilir, kendi dinamiklerini koruyabilir bölgesel ekonomik yapılar oluşturulması da okunmalıdır. Tüm fon destekleri ve programlar gibi, INTERREG ve ESPON da son dönemde bu üst anlayışla işleyecektir.

2002 yılından itibaren bilfiil uygulanmakta olan ESPON Programı, AB'nin Bölgesel Politikası ve Uyum Politikası kapsamında ciddi bir eksikliğin giderilmesi rolüyle yürürlüğe konmuştur. Mekansal gelişim perspektifinin ne kadar kazandırılmış olduğu ya da hangi dereceye kadar bunun başarılabileceği ayrı bir tartışma konusu olmakla birlikte, çok merkezli gelişme ekseninde, bu merkezler hakkında doğru yönelim kararlarının alınabilmesi için gerekli ortak teknik veri ve bilgilerin toplanması konusunda ESPON'un işlevsel yönü öne çıkmaktadır. Son dönemde Avrupa Komisyonu'nun programın içeriğine daha fazla ilgi duyduğu ve yönlendirici olarak daha fazla $\mathrm{AB}$ uyumunu gözettiği Program, bölgesel gelişme ve bölgeler arası farklılıkların daha sağlıklı ortaya konması, karşılaştırmalı bilgilerin sağlanabilmesi ve gerekli durumlarda gelecek senaryoları tasarlanması açısından, en azından etkili bir Yapısal destek aracı olarak karşımızda bulunmaktadır.

ESPON'u özel kılan bir başka özelliği de, proje uygulamalarının, iyi uygulamalar olarak yayılması, başka bölgelerde tekrarlanmasının önünün açık olmasıdır. Karar alıcıların Programın bilimsel yaklaşımını tamamen benimsemesinin zor olacağı gerçeği, Programın mekansal gelişme ve bölgesel düzeyleri tep tipleştirme gibi bir iddiasının ya da yöneliminin olmaması nedeniyle, kırılabilecek bir zorluktur. ESPON 2020 kapsamında bu konuda önlemler alınmakta ve yerel yönetimlerce uygulanabilir sadelikte bulguların yayılması konusunda düzenleme yapılmaktadır. Programın tanınması, sonuçlarının yayılması ve yönteminin gelecek araştırmalarda örnek alınması bile, ortak olmasa da ortağa yakın çözümler üretilebilmesinin yolunu açabilecek bir alternatiftir. 


\section{KAYNAKÇA}

ASSOCIATION OF EUROPEAN BORDER REGIONS (1997), The EU Initiative INTERREG and Future Developments, Gronau. (Çevrimiçi) http://www.aebr.eu/files/publications/interreg_97.en.pdf 9.2.2012.

BMBAU (1994), European Spatial Planning, Informal Council of Spatial Planning Ministers Leipzig, 21-22 September 1994, Bonn.

CAUDULLO, Francesco (2007), "The Creation and Development of the ESDP from Lisbon Strategy to the Third Report on Cohesion”, in Social Cohesion An Interpretative Proposal, Ed. Guido Nicolosi, Italy.

COMMISSION DECISION C (2007) 4222 of 11/IX/2007 adopting the operational programme "Interregional co-operation programme INTERREG IVC" for Community structural assistance from the European Regional Development Fund under the European territorial cooperation objective in all the Member States, with the participation of Norway and Switzerland.

(Çevrimiçi)

http://www.interreg4c.eu/uploads/media/pdf/about_the_programme_EC_decision.pdf 17.3.2012.

COMMISSION IMPLEMENTING DECISION of 16 June 2014 setting up the list of cooperation programmes and indicating the global amount of total support from the European Regional Development Fund for each programme under the European territorial cooperation goal for the period 2014 to 2020 (2014/366/EU), Official Journal L 178, 18.6.2014.

COMMISSION REGULATION (EC) No 1828/2006 of 8 December 2006 setting out rules for the implementation of Council Regulation (EC) No 1083/2006 laying down general provisions on the European Regional Development Fund, the European Social Fund and the Cohesion Fund and of Regulation (EC) No 1080/2006 of the European Parliament and of the Council on the European Regional Development Fund, Official Journal L 371, 27.12.2006.

COMMUNICATION FROM THE COMMISSION (2001/C 239/03) amending the guidelines for a Community initiative concerning trans-European cooperation intended to encourage the harmonious and balanced development of the European territory Interreg III, Official Journal C 239, 25.8.2001.

COMMUNICATION FROM THE COMMISSION COM(2010) 2020 final, EUROPE 2020: A Strategy for Smart, Sustainable and Inclusive Growth, Brussels, 3.3.2010. (Çevrimiçi)

http://eur-lex.europa.eu/LexUriServ/LexUriServ.do?uri=COM:2010:2020:FIN:EN:PDF 24.3.2013

COMMUNICATION FROM THE COMMISSION TO THE MEMBER STATES (2000/C 143/08) of 28 April 2000 laying down guidelines for a Community Initiative concerning trans-European cooperation intended to encourage harmonious and balanced development of the European territory Interreg III, Official Journal C 143, 23.5.2000.

COMMUNICATION FROM THE COMMISSION TO THE MEMBER STATES (2001/C 141/02) of 7 May 2001 INTERREGIONAL COOPERATION Strand C of the Interreg III Community initiative Commission communication C(2001) 1188 final, Official Journal C 141, 15.5.2001.

COMMUNICATION FROM THE COMMISSION TO THE MEMBER STATES (2004/C 226/02) of 2 September 2004 laying down guidelines for a Community initiative concerning transEuropean cooperation intended to encourage harmonious and balanced development of the European territory INTERREG III, Official Journal C 226, 10.9.2004 
COUNCIL REGULATION (EC) No 1083/2006 of 11 July 2006 laying down general provisions on the European Regional Development Fund, the European Social Fund and the Cohesion Fund and repealing Regulation (EC) No 1260/1999, Official Journal L 210, 31.7.2006.

COUNCIL REGULATION (EC) No 1260/1999 of 21 June 1999 laying down general provisions on the Structural Funds, Official Journal L 161, 26.6.1999.

DEMIRCİ, Mustafa ve GENÇ, F. Neval (2007), "Planlamanın Avrupa Birliği Boyutu", Dumlupınar Üniversitesi Sosyal Bilimler Dergisi, S: 19, s.53-74.

DERVIŞ, Kemal vd. (2004), Turkey and the EU Budget: Porspects and Issues, EU-Turkey Working Papers No 6, Center for European Policy Studies, Brussels.

DPT (2004), Türkiye'nin Üyeliğinin AB'ye Muhtemel Etkileri. (Çevrimiçi)

http://www.ibb.gov.tr/sites/Avrupa-Birligi/Documents/TRuyeliginAByemuhtemeletkileri.pdf $\underline{13.2 .2013}$.

DPT (2008), Dokuzuncu Kalkınma Planı 2007-2013 Bölgesel Gelişme Özel İhtisas Komisyonu Raporu, Yayın No 2766, DPT, Ankara.

ESPON 2013 Programme- European Observation Network on Territorial Development and Cohesion, Adopted by European Commission Decision C(2007) 5313 of 7 November 2007. (Çevrimiçi)

http://www.espon.eu/export/sites/default/Documents/Programme/ProgrammeRelatedDocum ents/OperationalProgramme/espon 2013 op-7-11-2007-approved.pdf 2.4.2011.

ESPON 2020 Draft Cooperation Programme (2014), For Public Consultation, Version 4 March 2014. (Çevrimiçi)

http://www.espon.eu/export/sites/default/Documents/Programme/ESPON2020/ESPON2020Consultati on/CP_PUBLIC_CONSULTATION_ESPON_2020-V5-4-3-2014.pdf (2.07.2014)

ESPON COORDINATION UNIT (2012), ESPON 2013 Programme ESPON Projects- Final Overview, Luxembourg. (Çevrimiçi)

http://www.espon.eu/export/sites/default/Documents/Projects/ProjectOverview/ESPON Project Over view_December_2012.pdf 7.5.2013.

ESPON Project 2.3.1 Application and Effects of the ESDP in the Member States, First Interim Report. (Çevrimiçi)http://www.espon.eu/export/sites/default/Documents/Projects/ESPON2006Projec ts/PolicyImpactProjects/ESDPImpact/1.ir_2.3.1.pdf 7.2.2012.

EUROPEAN COMMISSION (1999), ESDP European Spatial Development Perspective: Towards Balanced and Sustainable Development of the Territory of the European Union, Office for Official Publications of the European Communities, Luxembourg.

EUROPEAN COMMISSION (2004), A New Partnership for Cohesion: Convergence Competitiveness Cooperation, Third Report on Economic and Social Cohesion, Office for Official Publications of the European Communities, Luxembourg.

EUROPEAN COMMISSION (2006), Study on Territorial Cohesion, Lessons Learned from the ESPON Programme Projects and the Strategy for the Future, Final Report.

EUROPEAN COMMISSION (2007), Growing Regions, Growing Europe, Fourth Report on Economic and Social Cohesion, Office for Official Publications of the European Communities, Luxembourg.

EUROPEAN COMMISSION (2014), European Union Exlained: Regional Policy, Publications Office of the European Union, Luxembourg.

FINAL CONCLUSIONS issued by the German Presidency at the close of the Informal Council of EU Ministers responsible for Spatial Planning, Potsdam, 10-11 May 1999. (Çevrimiçi) 
http://ec.europa.eu/regional_policy/sources/docoffic/official/reports/pdf/concl_en.pdf 9.2.2012.

INTERREG EUROPE 2014-2020, CCI 2014 TC 16 RFIR 001 Cooperation Programme Document, 7 May 2014. (Çevrimiçi)

http://www.interreg4c.eu/fileadmin/User_Upload/PDFs/INTERREG_EUROPE_-_final.pdf

INTERREGIONAL COOPERATION PROGRAMME Interreg IVC (CCI 2007CB163PO046) Operational

Programme, 26 July 2007 (Updated on 9 September 2011). (Çevrimiçi)

http://www.interreg4c.eu/uploads/media/pdf/about the programme InterregIVC OP.pdf 17.3.2012.

MVA (2003), Mid-Term Evaluation of the ESPON 2006 Programme Final Report, Prepared for ESPON Co-ordination Unit, United Kingdom. (Çevrimiçi)

http://www.espon.eu/export/sites/default/Documents/Programme/ESPON2006Programme/MidtermEv aluation/fr_mid-term_eval-full.pdf 4.3.2011.

MVA (2005), ESPON Mid-Term Evaluation Update Final Report, Prepared for ESPON Co-ordination Unit, United Kingdom. (Çevrimiçi)

http://www.espon.eu/export/sites/default/Documents/Programme/ESPON2006Programme/MidtermEv aluation/mte final-report 26-9-2005.pdf 4.3.2011.

NOTICE C(90) 1562/3 to the Member States, laying down guidelines for operational programmes which Member States are invited to establish in the framework of a Community initiative concerning border areas (Interreg), Official Journal C 215, 30.8.1990.

NOTICE TO THE MEMBER STATES (94/C 180/13) laying down guidelines for operational programmes which Member States are invited to establish in the framework of a Community initiative concerning border development, cross-border cooperation and selected energy networks (INTERREG II), Official Journal C 180, 1.7.1994.

PANTEIA (2010), European Union Cohesion Policy, INTERREG III Community Initiative (20002006) Ex-Post Evaluation Final Report.

PRESIDENCY CONCLUSIONS, No. 2.4, EU Informal Ministerial Meeting on Territorial Cohesion, Luxembourg, 20/21 May 2005. (Çevrimiçi)

http://www.eu2005.lu/en/actualites/documents travail/2005/05/20regio/Min DOC 2 MinConcl fin.p df4.5.2011

PRESIDENCY CONCLUSIONS, No. 4.3, EU Informal Ministerial Meeting on Territorial Cohesion, Rotterdam, 29 November 2004. (Çevrimiçi)

http://www.arhiv.mop.gov.si/fileadmin/mop.gov.si/pageuploads/zakonodaja/konvencije/Rotterdam.pd f4.5.2011.

REGULATION (EC) No 1080/2006 of the European Parliament and of the Council of 5 July 2006 on the European Regional Development Fund and repealing Regulation (EC) No 1783/1999, Official JournalL 210, 31.7.2006.

REGULATION (EEC) No 724/75 of the Council of 18 March 1975 establishing a European Regional Development Fund, Official Journal L 73, 21.03.1975.

REGULATION (EU) No 1303/2013 OF THE EUROPEAN PARLIAMENT AND OF THE COUNCIL of 17 December 2013 laying down common provisions on the European Regional Development Fund, the European Social Fund, the Cohesion Fund, the European Agricultural Fund for Rural Development and the European Maritime and Fisheries Fund and laying down general provisions on the European Regional Development Fund, the European Social Fund, the Cohesion Fund and the European Maritime and Fisheries Fund and repealing Council Regulation (EC) No 1083/2006, Official Journal L 347, 20.12.2013. 
REVISED COMMUNITY INITIATIVE PROGRAMME, The ESPON 2006 Programme- Programme on the spatial development of an enlarging European Union, Approved by the European Commission on 18 December 2004. (Çevrimiçi)

http://www.espon.eu/export/sites/default/Documents/Programme/ESPON2006Programme/Community InitiativeProgramme/approved_revised_espon-cip_28.12.2004.pdf 4.3.2011.

RICHARDSON, Tim and JENSEN, Ole B. (2000), "Discourses of Mobility and Polycentric Development: A Contested View of European Spatial Planning", European Planning Studies, $\mathrm{V}: 8, \mathrm{~N}: 4, \mathrm{p}$. .

STUDY PROGRAMME ON EUROPEAN SPATIAL PLANNING Final Report, 31 March 2000. (Çevrimiçi) http://www.mcrit.com/SPESP/SPESP REPORT/SPESPDOCA/chapter\%201\%20\%20april.pdf17.3. 2012.

TERRITORIAL AGENDA OF THE EUROPEAN UNION: Towards a More Competitive and Sustainable Europe of Diverse Regions, Informal Ministerial Meeting on Urban Development and Territorial Cohesion, Leipzig, 24 - 25 May 2007. (Çevrimiçi) http://www.eu-territorial-agenda.eu/Reference\%20Documents/Territorial-Agenda-of-theEuropean-Union-Agreed-on-25-May-2007.pdf 13.4.2012.

WATERHOUT, Bas (2008), The Institutionalisation of European Spatial Planning, Sustainable Urban Areas 18, Delft University Press, The Netherlands. 